\title{
Lessons Learned from 50 Years of Hemoglobin Research: Unstirred and Cell-Free Layers, Electrostatics, Baseball Gloves, and Molten Globules
}

John S. Olson

\begin{abstract}
Significance: Over the past 50 years, the mechanisms for $\mathrm{O}_{2}$ storage and transport have been determined quantitatively on distance scales from millimeters to tenths of nanometers and timescales from seconds to picoseconds.

Recent Advances: In this review, I have described four key conclusions from work done by my group and our close colleagues. (i) $\mathrm{O}_{2}$ uptake by mammalian red cells is limited by diffusion through unstirred water layers adjacent to the cell surface and across cell-free layers adjacent to vessel walls. (ii) In most vertebrates, hemoglobins (Hbs) and myoglobins (Mbs), the distal histidine at the $\mathrm{E} 7$ helical position donates a strong hydrogen bond to bound $\mathrm{O}_{2}$, which selectively enhances $\mathrm{O}_{2}$ affinity, prevents carbon monoxide poisoning, and markedly slows autoxidation. (iii) $\mathrm{O}_{2}$ binding to mammalian $\mathrm{Hbs}$ and Mbs occurs by migration of the ligand through a channel created by upward rotation of the His(E7) side chain, capture in the empty space of the distal pocket, and then coordination with the ferroprotoporphyrin IX (heme) iron atom. (iv) The assembly of Mbs and Hbs occurs by formation of molten globule intermediates, in which the $\mathrm{N}$ - and $\mathrm{C}$-terminal helices have almost fully formed secondary structures, but the heme pockets are disordered and followed by high-affinity binding of heme.

Critical Issues: These conclusions indicate that there are often compromises between $\mathrm{O}_{2}$ transport function, holoprotein stability, and the efficiency of assembly.

Future Directions: However, the biochemical mechanisms underlying these conclusions provide the framework for understanding globin evolution in greater detail and for engineering more efficient and stable globins. Antioxid. Redox Signal. 32, 228-246.

Keywords: hemoglobin, myoglobin, $\mathrm{O}_{2}$ transport, $\mathrm{NO}$ deoxygenation, hemoglobin assembly, $\mathrm{O}_{2}$ binding

\section{Introduction}

$\mathbf{T}$ HIS REVIEW OF 50 years of hemoglobin $(\mathrm{Hb})$ research is based on my opening lecture for the XXth International Conference on Oxygen Binding and Sensing Proteins $\left(\mathrm{O}_{2} \mathrm{BIP}\right)$, held on September 3-6, 2018, at the University of Barcelona in Spain. It is not intended to be a comprehensive literature review of the various subject headings but, instead, provides a historical and personal view of my groups' major contributions to the four conclusions in the abstract. The topics were also chosen to complement and provide background for the other session speakers at the conference and their articles.

In 1968 when I started graduate work with Quentin H. Gibson at Cornell University, Perutz and his colleagues reported the first high-resolution crystal structure of $\mathrm{Hb}$ (77).

Then, he and Lehmann (75) published an article interpreting the clinical phenotypes of more than 100 different human hemoglobinopathies, setting the stage for structural interpretations of how globins function at the molecular, cellular, and tissue level. In effect, this article represented the first structure/function mutational analysis of a protein and served as a model for sitedirected mutagenesis studies that were to follow some 20 years later with the development of recombinant DNA technology. By the early 1970s, work with Hbs containing these naturally occurring point mutations led Perutz $(73,74)$ and others to develop detailed structural mechanisms for cooperative $\mathrm{O}_{2}$ binding to human $\mathrm{Hb}$, which with modifications have stood the test of time $(24,116)$, have been presented in most modern biochemistry text books [e.g., Nelson and Cox (60) and Storz (103)], and are summarized briefly in the next two paragraphs.
\end{abstract}

BioSciences Department, Rice University, Houston, Texas. 
Native human $\mathrm{Hb}$ is a tetramer that comprised $2 \alpha$ (141 amino acids) and $2 \beta$ (146 amino acids) monomers, which form two distinct sets of subunit interfaces [for structures and helical definitions in myoglobins (Mbs) and Hbs, see Nelson and Cox (60) and Storz (103)]. Monomers first form a heterodimer with strong hydrophobic interactions at what is called the $\alpha_{1} \beta_{1}$ interface. This interface remains unchanged when ligands bind either to this dimer in dilute solutions or to the tetramer under physiological conditions. Tetramer formation involves the association of these $\alpha_{1} \beta_{1}$ dimers to create two new $\alpha_{1} \beta_{2}$ and $\alpha_{2} \beta_{1}$ interfaces, which weaken greatly when $\mathrm{O}_{2}$ binds to the native deoxyhemoglobin tetramer. The change in conformation at the $\alpha_{1} \beta_{2}$ interfaces is the major cause of cooperative ligand binding $(60,73,74,116)$.

In the low-affinity or $\mathrm{T}$ state, the proximal histidine-Fe(II) complex is pulled away from the plane of the porphyrin ring by strong interactions of the F-helix with adjacent helices on the partner subunit at the $\alpha_{1} \beta_{2}$ interface. $\mathrm{O}_{2}$ binding requires in-plane movement of the iron atom, which is restricted in the deoxyhemoglobin conformation, and as a result, ligand affinity is low. After one subunit binds $\mathrm{O}_{2}$ pulling its iron atom into the porphyrin plane, the interactions at the $\alpha_{1} \beta_{2}$ interface are weakened by movement of the F-helix away from the partner subunit. This ligand-induced change "frees up" the proximal constraints in the adjacent subunit, allowing inplane movement of the His(F8)-Fe complex and greater reactivity of the iron atom. A key issue of debate has been whether or not these ligand-induced changes at the $\alpha_{1} \beta_{2}$ interface occur stepwise or are concerted with a single conformational change of the entire tetramer [see Yuan et al. (116) and Eaton et al. (24) and references therein]. Regardless, it is clear that decreases in proximal stereochemical constraints are the underlying cause for the increase in $\mathrm{O}_{2}$ affinity in $\mathrm{Hb}$ as progressive binding occurs.

Later studies with recombinant globins in the 1990s showed that proximal constraints also regulate $\mathrm{O}_{2}$ binding in monomeric globins. In these cases, it is often the orientation of the proximal histidine that regulates iron reactivity [see Olson and Ghosh (65)]. When the edges of the proximal imidazole in the unliganded protein are located in an eclipsed conformation right underneath the pyrrole $\mathrm{N}$ atoms, movement of the high-spin iron into the plane of the ring is inhibited, decreasing both association rates and affinities for $\mathrm{O}_{2}$ binding. This eclipsed conformation is seen in mammalian Mbs that have moderate affinities $\left(\mathrm{P}_{50} \geq 1 \mu M\right.$ or $\left.0.6 \mathrm{~mm} \mathrm{Hg}\right)$. In contrast, leghemoglobin and many invertebrate globins have staggered imidazole/pyrrole nitrogen geometries and conformations that facilitate in-plane movement of the iron, accounting for their ultrahigh ligand affinities $\left(\mathrm{P}_{50}\right.$ for $\left.\mathrm{O}_{2} \leq 0.1 \mu M\right)(22,36,65)$.

My graduate studies at Cornell focused on trying to measure differences in the ligand binding rate constants of the $\alpha$ and $\beta$ subunits within tetrameric human $\mathrm{Hb}$. Because sitedirected mutagenesis was not available, we chose to explore the accessibility and iron reactivities of the subunits using larger alkyl isocyanide ligands, adopting an approach that was pioneered by St. George and Pauling (102) and then used by Antonini and Brunori's group in Rome (105). One motivation was Perutz's suggestion in his classic 1970 article that ligands could not bind to $\beta$ subunits in deoxyhemoglobin until ligands bound to $\alpha$ subunits causing a switch to the $\mathrm{R}$ or high-affinity conformation (73). He proposed that access to the iron atom in $\beta$ subunits was sterically restricted. However, our experimental kinetic results suggested the opposite conclusion. Ligands bind to and are released from $\beta$ subunits more rapidly than $\alpha$ subunits in both the low- and highaffinity quaternary states, but the equilibrium constants for the subunits are identical, a property that is required for cooperative ligand binding $(66,84)$. The differences in accessibility for entry and exit depended on ligand size, with $\beta$ subunits showing 2-fold higher rates of association and dissociation for $\mathrm{O}_{2}$ binding and 10- to 20-fold higher rates for the larger ligand, n-butyl isocyanide (84).

After a year of postdoctoral studies on xanthine oxidase and related molybdoflavoproteins with Vincent Massey and Graham Palmer at the University of Michigan, I took an assistant professor position at Rice University in the summer of 1973. Later in that year, Graham Palmer decided to take a senior faculty position at Rice. His decision allowed us to continue working together on xanthine oxidase, but, at the same time, I had to establish an independent program so I went back to studies of $\mathrm{O}_{2}$ transport by globins.

Part of our early work at Rice University involved systematically looking at the effects of ligand size and chemistry on the parameters for ligand binding to native human $\mathrm{Hb}$ and related globins. We expanded our studies to include a complete series of alkyl isocyanides [from methyl to hexyl, including various stereoisomers (84)] and more detailed comparisons between $\mathrm{O}_{2}$, nitric oxide (NO), and carbon monoxide (CO) $(43,56)$. The isocyanides served as "substrate analogs" to map out steric restrictions in the active sites of $\mathrm{Mb}$ and the $\alpha$ and $\beta$ subunits of $\mathrm{Hb}$ (56). However, these initial maps were empirical and not very satisfying until crystal structures of the isocyanide complexes were determined $(7,8,99)$. Detailed mechanistic comparisons between $\mathrm{O}_{2}$, NO, and $\mathrm{CO}$ had to wait until libraries of site-directed mutants and ultrafast-laser photolysis techniques could be used to measure directly individual rates of ligand entry, exit, and bond formation within the various globins.

\section{Unstirred and Cell-Free Layers}

In the late 1970s and 1980s, we also examined quantitatively the factors that govern $\mathrm{O}_{2}$ uptake and release by $\mathrm{Hb}$ encapsulated in red cells, either in simple rapid mixing experiments or during flow in capillaries. The motivation was threefold: (i) the experiments and analyses were intellectually challenging and had not been done systematically; (ii) the results were crucial to understanding the factors that govern $\mathrm{O}_{2}$ transport in vivo and in developing hemoglobinbased oxygen carriers (HBOCs) for transfusion therapy; and (iii), more selfishly, it was important for me to set up a research program that was distinct from my $\mathrm{PhD}$ advisor, Quentin Gibson, who was developing laser photolysis technology to examine the kinetics of cooperative ligand binding and associated conformational transitions in human $\mathrm{Hb}$.

The first question to answer was why, in simple rapid mixing experiments, human red cells take up oxygen so much more slowly than $\mathrm{Hb}$ free in solution. An example from our own work using a Gibson-Dionex stopped-flow apparatus is shown in Figure 1 (17). In this experiment, either free $\mathrm{Hb}$ or a suspension of red cells was mixed 1:1 with air-equilibrated, isotonic phosphate buffer. Absorbance increases at $576 \mathrm{~nm}$ $\left(\mathrm{HbO}_{2}\right.$ peak) and decreases at $560 \mathrm{~nm}$ (deoxyHb peak) were measured simultaneously and then subtracted to increase the 
1. Simple reaction of $\mathrm{Hb}$ with $\mathrm{O}_{2}$ in isotropic solution.

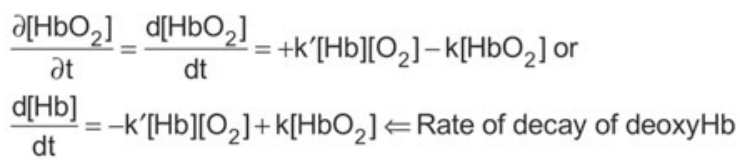

2. Diffusion through the viscous cell cytoplasm and reaction with intracellular deoxyHb

$\frac{\partial\left[\mathrm{O}_{2}\right]}{\partial \mathrm{t}}=\mathrm{D}_{\mathrm{O}_{2}} \frac{\partial^{2}\left[\mathrm{O}_{2}\right]}{\partial \mathrm{x}}-\mathrm{k}^{\prime}[\mathrm{Hb}]\left[\mathrm{O}_{2}\right]+\mathrm{k}\left[\mathrm{HbO}_{2}\right]$

$\frac{\partial\left[\mathrm{HbO}_{2}\right]}{\partial \mathrm{t}}=\mathrm{D}_{\mathrm{HbO}_{2}} \frac{\partial^{2}\left[\mathrm{HbO}_{2}\right]}{\partial \mathrm{x}}+\mathrm{k}^{\prime}[\mathrm{Hb}]\left[\mathrm{O}_{2}\right]-\mathrm{k}\left[\mathrm{HbO}_{2}\right]$
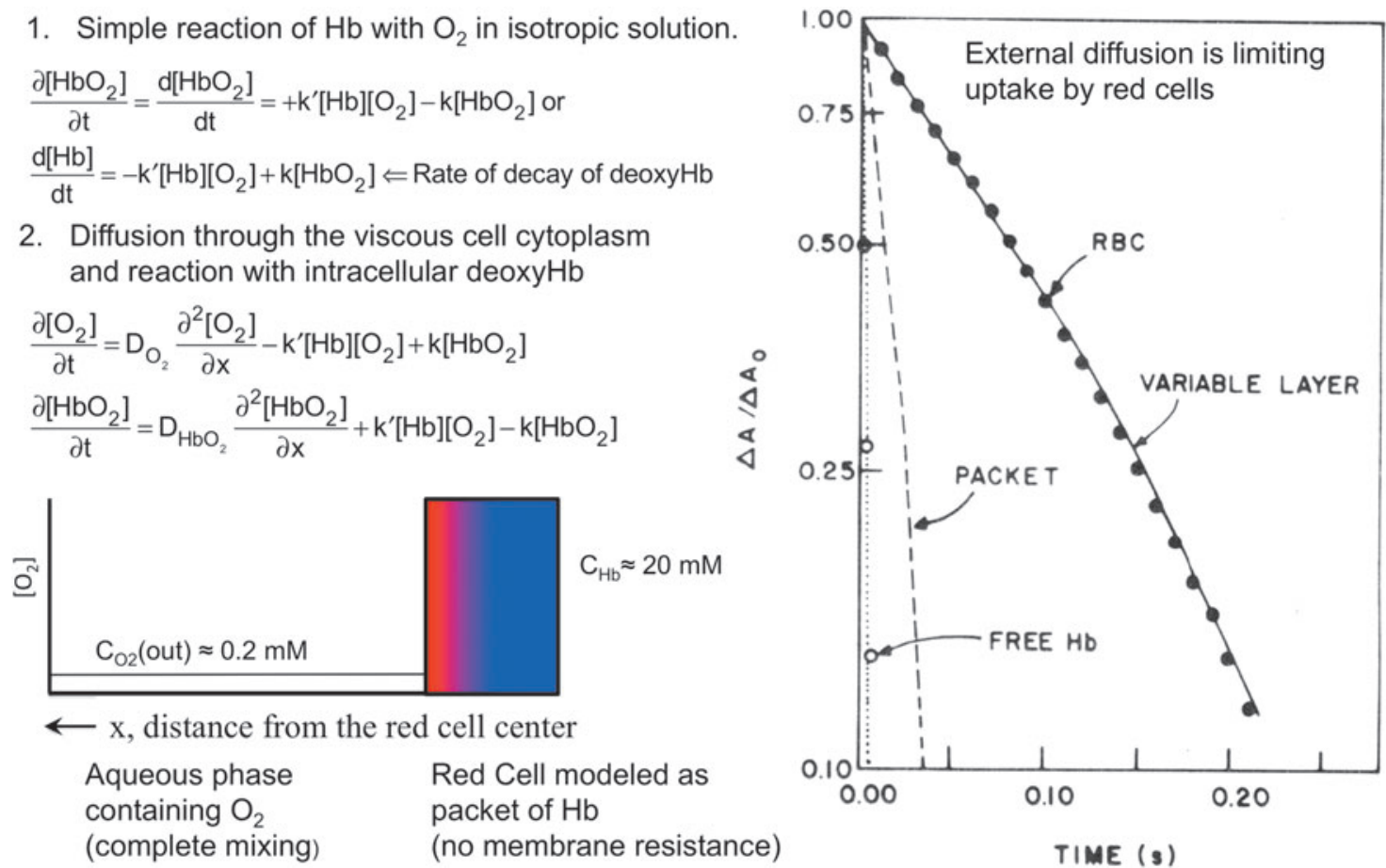

FIG. 1. $\mathrm{O}_{2}$ uptake by human RBCs in rapid mixing experiments. The time courses in the right-hand panel were taken from Coin and Olson (17), where a deoxygenated red cell suspension was mixed with air equilibrated buffer at $\mathrm{pH} 7,20^{\circ} \mathrm{C}$. The equations on the left describe: [1] the kinetics of $\mathrm{O}_{2}$ binding to $\mathrm{Hb}$ free in solution, which only depends on the expressions for the chemical reactions of the ligand with $\mathrm{Hb}$; and [2] the combination of diffusion and chemical reaction terms that are required to describe $\mathrm{O}_{2}$ binding to $\mathrm{Hb}$ in erythrocytes. Note that the first differential term describing $\mathrm{O}_{2}$ diffusion (Fick's second law) also needs to be integrated in volume elements outside the cell if there is no mixing. The diagram in the lower left describes a simple packet model for $\mathrm{O}_{2}$ uptake by red cells where only the equations shown in [2] for chemical reaction and diffusion inside the cell are integrated. Hb, hemoglobin; RBC, red blood cell.

signal for $\mathrm{O}_{2}$ binding and to cancel out light scattering effects, which were large and complex due to the change from turbulent to laminar flow followed by no stirring and cell settling.

As shown in Figure 1, the reaction with free $\mathrm{Hb}$ is very rapid with a half time on the order of $\sim 2 \mathrm{~ms}$, and much of the reaction occurs in the dead time of the apparatus ( $\sim 2 \mathrm{~ms})$. In contrast, uptake of $\mathrm{O}_{2}$ by red cells containing the same amount of $\mathrm{Hb}$ is dramatically slower, with a half time of $\sim 80 \mathrm{~ms}$. Hartridge and Roughton (42) observed this same difference in 1927 using the first successful rapid mixing device for measuring $\mathrm{Hb}$ oxygenation. In his original article and several later publications, Roughton suggested that part of the slowing was due to the need for $\mathrm{O}_{2}$ to diffuse through the dense cytoplasm of the red cell to reach all the $\mathrm{Hb}$ molecules $(42,61,86)$. When this diffusion resistance is simulated using a packet model of $\mathrm{Hb}$ surrounded by well-mixed buffer (Fig. 1, left bottom panel), the rate of $\mathrm{O}_{2}$ uptake does slow down approximately eightfold, yielding a half-time of $\sim 16 \mathrm{~ms}$. However, the measured rate of uptake by red cells is still approximately fivefold slower (Fig. 1, right panel).

Roughton and colleagues correctly concluded that slow $\mathrm{O}_{2}$ uptake by red cells is due to external diffusion processes, whereas chemical reaction with internal $\mathrm{Hb}$ is much faster and not limiting $(42,61,86)$. He and others suggested that the limiting process was diffusion through the red cell membrane and proposed that the $\mathrm{O}_{2}$ movement across the lipid bilayer was $\sim 5$ to 10 times slower than the movement through an equivalent volume of buffer or cell cytoplasm. As shown in Figure 2 and Equations 1-3, his membrane model indicates that the rate of $\mathrm{O}_{2}$ uptake can be approximated by a simple interpretation of Fick's first law for diffusion across the red cell membrane. The flux, $\mathrm{J}_{\mathrm{O} 2}$, in molecules of $\mathrm{O}_{2}$ per cross-sectional area across the membrane is given by the following:

$$
\begin{aligned}
\mathrm{J}_{\mathrm{O}_{2}}\left(\frac{\text { molecules }}{\mathrm{cm}^{2}}\right) & =-\mathrm{D}_{\mathrm{M}}\left(\frac{\mathrm{d}\left[\mathrm{O}_{2}\right]}{\mathrm{dz}}\right)_{\text {membrane }} \\
& \approx-\mathrm{D}_{\mathrm{M}} \frac{\left(\mathrm{C}_{\text {cell }}-\mathrm{C}_{\text {out }}\right)}{\Delta \mathrm{X}_{\mathrm{m}}}
\end{aligned}
$$

where $\mathrm{D}_{M}$ is the diffusion constant for $\mathrm{O}_{2}$ in the cell membrane, $\Delta \mathrm{X}_{\mathrm{m}}$ is the thickness of the membrane, and $\mathrm{C}_{\text {out }}$ and $\mathrm{C}_{\text {cell }}$ are the concentrations of free $\mathrm{O}_{2}$ outside and inside the cell, respectively. If this diffusion process is rate limiting for uptake, then the rate of increase in internal $\left[\mathrm{O}_{2}\right]$ will be given by the flux times the surface area divided by the volume of the cell. Assuming a high concentration of internal $\mathrm{Hb}$ $(\sim 20,000 \mu M)$ and a relatively high affinity $\left(\mathrm{P}_{50} \approx 10\right.$ $20 \mu M$ or 6 to $12 \mathrm{~mm} \mathrm{Hg}$ ), every molecule of $\mathrm{O}_{2}$ that enters the cell will quickly be bound to deoxyhemoglobin. Under these conditions, the rate of saturation of the internal $\mathrm{Hb}$ can be approximated by the following:

$$
\frac{\mathrm{dC}_{\mathrm{cell}}}{\mathrm{dt}} \approx-\frac{\mathrm{SA}}{\mathrm{V}} \mathrm{D}_{\mathrm{M}} \frac{\left(\mathrm{C}_{\mathrm{cell}}-\mathrm{C}_{\mathrm{out}}\right)}{\Delta \mathrm{X}_{\mathrm{m}}} \approx \frac{\mathrm{d}\left[\mathrm{HbO}_{2}\right]}{\mathrm{dt}}=-\frac{\mathrm{d}[\mathrm{Hb}]}{\mathrm{dt}}
$$




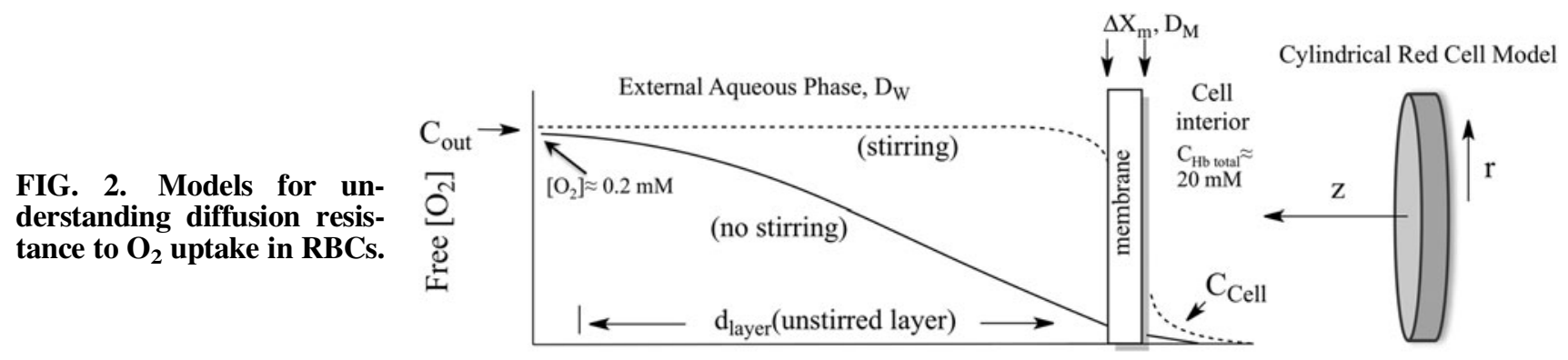

$z$, distance from the surface of the cell

As a result, the rate of decay of deoxyHb is diffusion limited and appears zero order, accounting for the curvature (acceleration) in the logarithmic plot shown in the right panel of Figure 1. The idea that $\mathrm{O}_{2}$ uptake by red cells is limited by diffusion through the erythrocyte membrane persisted up until the early 1970 s when my group became interested in the problem. However, by then, it was becoming clear that membranes offer little resistance to the diffusion of any of the physiologically relevant diatomic gases $\left(\mathrm{N}_{2}, \mathrm{O}_{2}, \mathrm{CO}\right.$, and NO) (51). Measurements of $\mathrm{O}_{2}$ diffusion constants, $\mathrm{D}_{\mathrm{m}}$, in biological membranes suggested a three- to fourfold reduction compared with the values in water. However, the solubility of $\mathrm{O}_{2}$ in membranes is roughly three- to fourfold higher, which compensates for the slower movement. As a result, the net rate of transport of $\mathrm{O}_{2}$ across most biological membranes is the same as that across a similar volume element of solvent if the gradients are the same (111).

Instead of slow diffusion in the membrane, the major external resistance in red cell uptake experiments is the need for most of the $\mathrm{O}_{2}$ to diffuse through unstirred layers of solvent adjacent to the surface (Fig. 2). This problem arises from the high concentration of $\mathrm{Hb}$ present in the red cells, $\sim 20 \mathrm{~m} M \mathrm{Hb}$ subunits, compared with the free concentration of $\mathrm{O}_{2}$ in air equilibrated buffer, $\sim 0.2 \mathrm{~m} M$. If the thickness of a human red cell is $\sim 1.6 \mu \mathrm{m}$, then it would take a slab of buffer $\sim 160 \mu \mathrm{m}$ thick to provide enough $\mathrm{O}_{2}$ to saturate the internal $\mathrm{Hb}$. Gad-El-Hak et al. (30), Kutchai (52), and others suggested that these unstirred layers are the major cause for slow uptake of $\mathrm{O}_{2}$ by either stationary or red cells in stopped-flow, rapid mixing experiments.

Very quickly after flow stops in rapid mixing experiments, a "steady-state", gradient forms at the surface of the red cell and extends out to roughly $8-10 \mu \mathrm{m}(17)$. The $\left[\mathrm{O}_{2}\right]$ inside the cell $\left(\mathrm{C}_{\text {cell }}\right.$ in Fig. 2$)$ is roughly zero due to combination with deoxy $\mathrm{Hb}$ and the concentration of external $\mathrm{O}_{2}$ does not reach that in bulk solvent, $\mathrm{C}_{\text {out }}$ in Figure 2, until about $10 \mu \mathrm{m}$ away from the flatter surface of the cell. In our and Roughton's initial models, the red cell was approximated as a thin slab using a single distance parameter in the $\mathrm{z}$ direction in Figure 2 (17). We later examined systematically the unstirred layer diffusion problem using spherical and cylindrical models for human erythrocytes and taking into account the increase in the effective unstirred layer as the red cells are exposed to turbulent flow in the mixer, transient laminar flow as the mixture moves through the observation cuvette, and then no convective mixing shortly after flow stops (111). We were able to simulate quantitatively the shapes and dependences of time courses for $\mathrm{O}_{2}$ uptake on ligand concentration, internal $\mathrm{Hb}$ concentration, and external viscosity using cylindrical coordinates and the time dependence of the unstirred layer $\left(\mathrm{d}_{\text {layer }}\right.$, Fig. 2) after mixing (111).

Detailed analyses of $\mathrm{O}_{2}$ uptake and resistance due to unstirred layers are very complex and require solving partial second-order differential equations for both $\left[\mathrm{HbO}_{2}\right]$ and $\left[\mathrm{O}_{2}\right]$ inside the red cell and $\left[\mathrm{O}_{2}\right]$ outside. However, the overall rate of uptake can be approximated by an expression similar to that derived for Roughton's original membrane limitation model (Eq. 2). If the rate of uptake is limited only by the flux across the unstirred, external layer, the net rate of $\mathrm{O}_{2}$ uptake by the cell, $\mathrm{d}\left[\mathrm{O}_{2}\right]_{\text {total }} / \mathrm{dt} \approx \mathrm{d}\left[\mathrm{HbO}_{2}\right]_{\text {cell }} / \mathrm{dt}$, can be approximated by the following:

$$
\begin{aligned}
\mathrm{J}_{\mathrm{O}_{2}}\left(\frac{\text { molecules }}{\mathrm{cm}^{2}}\right) & =-\mathrm{D}_{\mathrm{w}}\left(\frac{\mathrm{d}\left[\mathrm{O}_{2}\right]}{\mathrm{dz}}\right)_{\text {layer }} \\
& \approx-\mathrm{D}_{\mathrm{w}} \frac{\left(\mathrm{C}_{\text {cell }}-\mathrm{C}_{\text {out }}\right)}{\mathrm{d}_{\text {layer }}} \text { and } \\
\frac{\mathrm{d}\left[\mathrm{HbO}_{2}\right]}{\mathrm{dt}} & \approx-\frac{\mathrm{SA}}{\mathrm{V}} \mathrm{D}_{\mathrm{w}} \frac{\left(\mathrm{C}_{\text {cell }}-\mathrm{C}_{\text {out }}\right)}{\mathrm{d}_{\text {layer }}}
\end{aligned}
$$

Again, the reaction is zero order with respect to [deoxyHb] (i.e., no chemical reaction limitation), but does depend linearly on $\left[\mathrm{O}_{2}\right]$ in the solvent, $\mathrm{C}_{\mathrm{out}}$, and the diffusion constant of $\mathrm{O}_{2}$ in the solvent phase, $\mathrm{D}_{\mathrm{w}}$. Coin and Olson (17) verified this interpretation by showing that the observed rate of uptake depends inversely on the viscosity of the solvent phase using high concentrations of serum albumin and Stractan, an arabinoglactan polymer, to lower $\mathrm{D}_{\mathrm{w}}$.

Equation 3 also provides a semiquantitative explanation of the dramatic dependence of the rate of $\mathrm{O}_{2}$ uptake on red cell size (Fig. 3, right panel). In 1966, Holland and Forster (44) measured the apparent bimolecular rate of $\mathrm{O}_{2}$ uptake by red cells, $\mathrm{k}_{\mathrm{O} 2}^{\prime}$, for a series of animal red cells with significantly different mean corpuscular volumes. We extended the range of sizes using large nucleated red cells (diameter $\approx 50 \mu \mathrm{m}$, thickness $\approx 6 \mu \mathrm{m}$ ) from the salamander, Amphiuma means, and artificial red cells generated by encapsulating human $\mathrm{Hb}$ in liposomes (diameter $\approx 0.2 \mu \mathrm{m}$, spheres), using human red cells as our control (diameter $\approx 8 \mu \mathrm{m}$, thickness $\approx 1.6 \mu \mathrm{m}$ ) (Fig. 3) (110). The values of $\mathrm{k}_{\mathrm{O} 2}^{\prime}$ were taken from the slopes of plots of the observed rates of $\mathrm{O}_{2}$ uptake as function of $\left[\mathrm{O}_{2}\right]$ or $\mathrm{C}_{\text {out }}$ in Equation 3. As shown in the right-hand panel in Figure 3, the apparent bimolecular rate of $\mathrm{O}_{2}$ uptake, $\mathrm{k}_{\mathrm{O} 2}^{\prime}$, depends markedly on the surface area to volume (S/A) ratio of the red cell. The rate for artificial cells is off the observed scale and is roughly equal to the bimolecular rate for binding to acellular $\mathrm{Hb}$, indicating little or no diffusion limitation. 

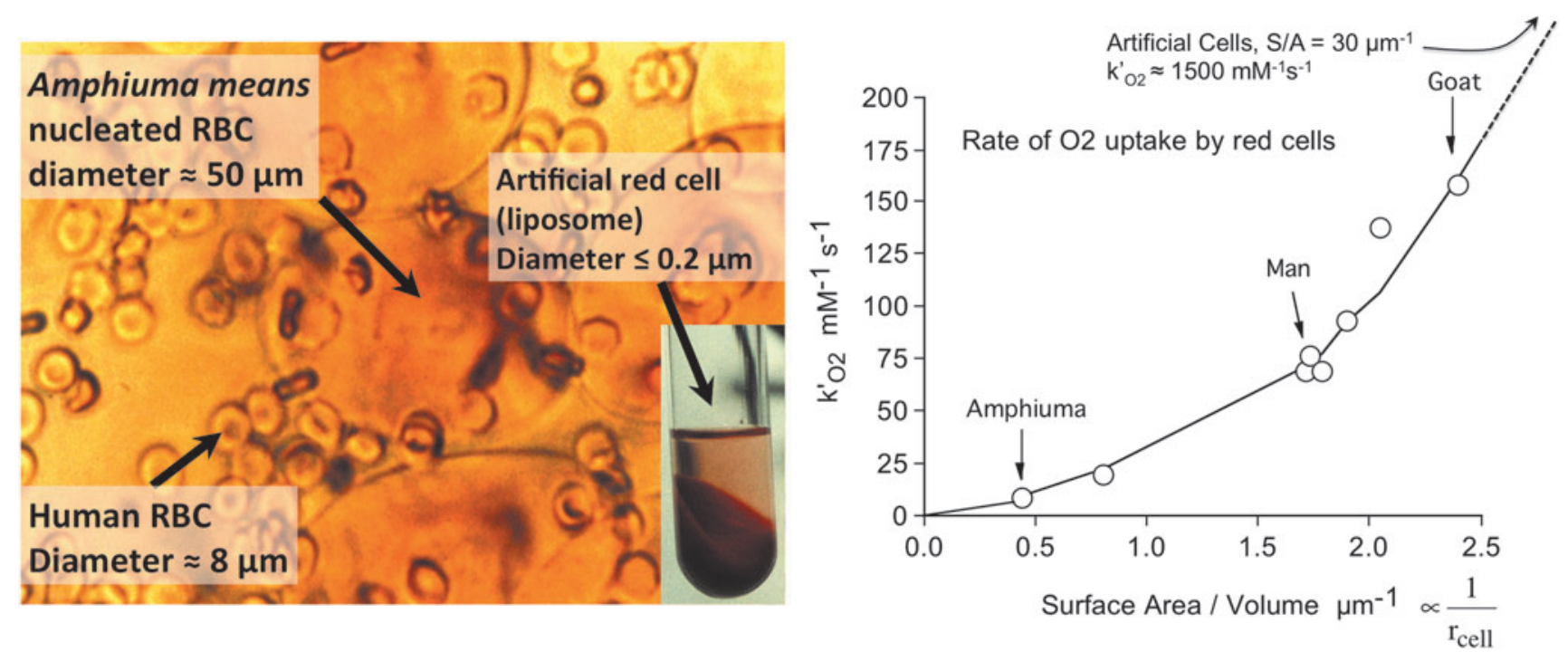

FIG. 3. Dependence of the rate of $\mathrm{O}_{2}$ uptake on red cell size. The data in the right-hand panel were taken from Vandegriff and Olson (110) and Holland and Forester (44).

The latter result also argues strongly against any limitation by diffusion of $\mathrm{O}_{2}$ across a lipid bilayer.

The unstirred layer model described by Equation 3 explains the parabolic dependence of the rate of $\mathrm{O}_{2}$ uptake on the S/A ratios of the different animal erythrocytes shown in Figure 3. If the cells were spherical, the S/A ratio would be given by $3 / \mathrm{r}_{\text {cell }}$. The thickness of the unstirred layer in the steady state is roughly equal to the radius of the cell (i.e., $\mathrm{d}_{\text {layer }} \approx \mathrm{r}_{\text {cell }}$ ), particularly for spherical shapes (111). Thus, Equation 3 reduces to the following:

$$
\frac{\mathrm{d}\left[\mathrm{HbO}_{2}\right]}{\mathrm{dt}} \approx-\frac{3}{\mathrm{r}_{\text {cell }}^{2}} \mathrm{D}_{\mathrm{w}}\left(\mathrm{C}_{\text {cell }}-\mathrm{C}_{\text {out }}\right)
$$

The observed bimolecular rate of $\mathrm{O}_{2}$ uptake is predicted to depend parabolically on the S/A ratio of red cells, which for a sphere would be proportional to the reciprocal of the radius squared. Thus, the large red cells of amphibians are poor at taking up and releasing $\mathrm{O}_{2}$. These animals rely primarily on anaerobic skeletal muscle metabolism, whereas ruminants have the smallest red cells, which allow more efficient $\mathrm{O}_{2}$ transport for aerobic skeletal muscle metabolism $(44,110)$. The results in Figure 3 also explain why the fastest growing aerobic bacteria are small and nonspherical to enhance their S/A ratios and why unicellular microorganisms have often evolved flagella to stir themselves with random motions to reduce the resistance to diffusion of metabolites up to their surfaces (110).

In larger complex animals, circulatory systems evolved to push red cells through small capillaries under conditions of laminar or turbulent flow to reduce the unstirred layers to roughly $1-3 \mu \mathrm{m}$ compared with $\sim 10 \mu \mathrm{m}$ when no stirring is occurring. This convective mixing greatly enhances the rate of $\mathrm{O}_{2}$ uptake and release, using the mechanical energy created by heart muscle contractions. However, an additional diffusive resistance occurs as cells flow through blood vessels due to the Fåhraeus effect, which describes how large particles tend to accumulate in the center of small tubes where the fluid velocity is maximal. As a result, cell-free layers are created adjacent to the vessel walls, and free $\mathrm{O}_{2}$ must diffuse through these layers before reaching the endothelium and the tissues on the other side of the vessel walls.

In collaboration with Dr. J. David Hellums' group in the Chemical Engineering Department at Rice University, we constructed artificial capillary, microspectrophotometer systems to investigate the factors that govern $\mathrm{O}_{2}$ transport under conditions simulating red cell flow in human blood vessels. Detailed descriptions of the apparatus and analyses of the observed transport curves are given in a series of articles between 1987 and 1997 (10, 53, 70-72). A color-enhanced view of the cell-free layer during red cell flow is shown in Figure 4 under conditions resembling the situation in human arterioles (69).

Although the thickness of this layer is small, Hellums' and our groups showed that the diffusion resistance due to this layer and that due to the small unstirred layer surrounding the red cells causes a two- to threefold decrease in the efficiency of $\mathrm{O}_{2}$ uptake and release by red cells compared with solutions of acellular $\mathrm{Hb}$ with the same total $\mathrm{Hb}$ concentration. Hellums and his students showed that this same twofold decrease in efficiency also occurs in small-bore capillaries due to "slug" flow of the cells $(3,71)$. In this situation, the vessel wall is in direct contact with a red cell with high rates of $\mathrm{O}_{2}$ transport for a short period of time followed by a similar period of time in which only plasma contacts the wall and little transport occurs. In contrast, high rates of transfer are continuous if an equivalent amount of acellular $\mathrm{Hb}$ is present.

There are three key take-home lessons from our work with red cells. First, small cells, small vessels, and laminar or turbulent flow are required for efficient $\mathrm{O}_{2}$ transport to reduce both the unstirred layers adjacent to the red cell surface and the cell-free layers adjacent to the blood vessel wall. Even when these factors are optimized, cell-free $\mathrm{Hb}$ is always $\geq 2$ times more efficient at transporting $\mathrm{O}_{2}$ in capillary systems than red cells. This conclusion raises the question why animals retained red cells for $\mathrm{O}_{2}$ transport. The two main reasons 


\section{Streaming of red cells in an in-vitro capillary system}

1. $0 \mu \mathrm{l} / \mathrm{hr}$ flow, human red cells in a $27 \mu \mathrm{m}$ capillary

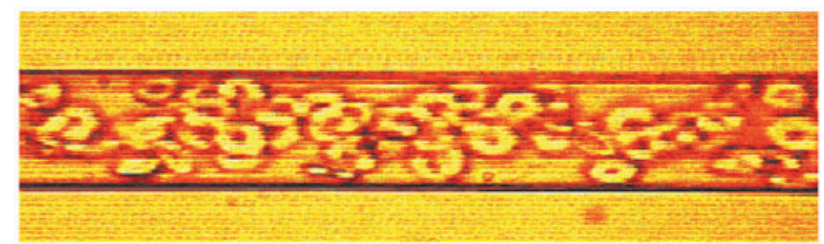

FIG. 4. Color-enhanced views of red cells flowing through the artificial capillary device are described in Page's (69) PhD thesis dissertation and were adapted with his permission from his defense presentation.

\section{2. $\sim 5 \mu \mathrm{L} / \mathrm{hr}$ flow, human red cells in a $27 \mu \mathrm{m}$ capillary}

3. $\sim 50 \mu \mathrm{l} / \mathrm{hr}$ flow, human red cells in a $27 \mu \mathrm{m}$ capillary

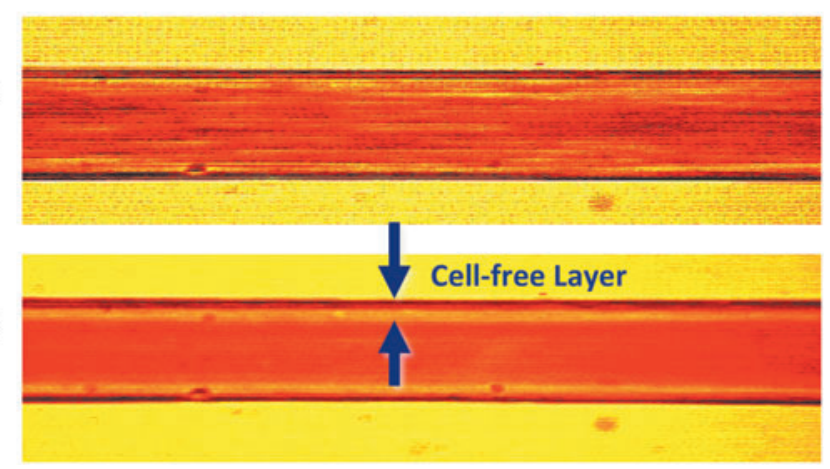

are as follows: (i) to decrease oncotic pressure by reducing the number of discrete solutes and particles in blood, and (ii) to provide metabolic pathways for preventing $\mathrm{Hb}$ oxidation and degradation, which occur relatively rapidly (1-2 days) for purified $\mathrm{Hb}$ at $37^{\circ} \mathrm{C}$. Degradation of acellular $\mathrm{Hb}$ leads to vascular damage if red cell lysis occurs in vivo. In addition, acellular $\mathrm{Hb}$ can penetrate blood vessel walls, scavenge NO, interfere with smooth muscle relaxation, and cause hypertension. Despite degradation problems, however, acellular $\mathrm{Hb}$ is more efficient at transporting $\mathrm{O}_{2}$, which explains why acellular HBOCs can sustain effective tissue oxygenation at $\mathrm{Hb}$ concentrations two- to threefold less $(-4$ to $5 \mathrm{~g} / \mathrm{dL})$ than that of whole blood ( 10-15 g/dL) $(18,20,21,28,72)$.

The second key lesson from our red cell studies is that efficient release of $\mathrm{O}_{2}$ in muscle and neuronal tissue capillaries requires a high $\mathrm{P}_{50}$ because the rate of transfer is determined by the flux across the capillary wall. This flux is proportional to the $\mathrm{O}_{2}$ concentration gradient. At $50 \%$ unloading, this gradient is roughly the free $\left[\mathrm{O}_{2}\right]$ in the blood, which is given by the $\mathrm{P}_{50}$ of the red cell $\mathrm{Hb}$, minus the free $\left[\mathrm{O}_{2}\right]$ in the muscle or neuronal tissue, which is $\sim 0$ due to high rates of mitochondrial respiration. Thus, the rate of $\mathrm{O}_{2}$ efflux through capillaries into actively respiring tissues is proportional to the $\mathrm{P}_{50}$ of the red cell $\mathrm{Hb}$. Lower oxygen affinity (higher $\mathrm{P}_{50}$ ) normally leads to more rapid unloading and greater extents of transport because of the higher rates of diffusion across the vessel walls.

In alveolar capillaries, the gradient at $50 \%$ uptake is given by the free $\left[\mathrm{O}_{2}\right]$ in the liquid part of the alveolar sacs minus the free $\left[\mathrm{O}_{2}\right]$ in the blood, which again is roughly equal to the $\mathrm{P}_{50}$ of the red cell $\mathrm{Hb}$. In the alveolar fluid equilibrated with air, $\left[\mathrm{O}_{2}\right]_{\text {free }} \approx 250 \mu \mathrm{M}$ or $\sim 150 \mathrm{~mm} \mathrm{Hg}$, whereas $\mathrm{P}_{50}$ for the red cell $\mathrm{Hb}$ is $\sim 15-30 \mu M$ or $9-18 \mathrm{~mm} \mathrm{Hg}$, depending on $\mathrm{pH}$ and intracellular 2,3 bisphosphoglycerate concentration. Thus, the flux or rate of $\mathrm{O}_{2}$ uptake is roughly independent of the $\mathrm{P}_{50}$ of the $\mathrm{Hb}$ sample, unless it becomes abnormally high, that is, $\mathrm{P}_{50} \geq 100 \mu M$ or $60 \mathrm{~mm} \mathrm{Hg}$. The large oxygen concentration gradient in the lung vessels also facilitates almost complete saturation of red cell $\mathrm{Hb}$ during the brief time spent in the alveolar capillaries ( 0.5 to $1 \mathrm{~s})$, whereas the 10 -fold smaller gradients across muscle and neuronal capillaries prevent complete unloading and limit the overall extent of $\mathrm{O}_{2}$ transport from the lungs to respiring tissue. Animals that need high rates of transport have large numbers of capillary beds, small red cells, highly cooperative intracellular $\mathrm{Hb}$, and mechanisms for increasing $\mathrm{P}_{50}$ markedly by the binding of organic phosphates, protons (alkaline Bohr effect), and carbon dioxide.

The third key conclusion is that under most physiological situations, external diffusion processes limit $\mathrm{O}_{2}$ uptake and release across the red cell membrane and the blood vessel wall and not chemical reaction with the ferroprotoporphyrin IX (heme) iron atoms in the protein. We and others have shown both theoretically and experimentally that if the ligand association rate constant for reaction with free $\mathrm{Hb}, \mathrm{k}_{\mathrm{O} 2}^{\prime}$, is $\geq \sim 1 \times 10^{6} M^{-1} \mathrm{~s}^{-1}$ and the dissociation rate constant, $\mathrm{k}_{\mathrm{O} 2}$, is $\geq \sim 10 \mathrm{~s}^{-1}$, there is no dependence of the time course of uptake and release of $\mathrm{O}_{2}$ by red cells on the absolute values of these parameters in either simple rapid mixing or capillary experiments $(53,111)$. However, as described above, the ratio of these constants, which defines the overall oxygen affinity of the $\mathrm{Hb}$, does matter because the $\mathrm{P}_{50}$ value defines the gradient across capillary walls during release in actively respiring muscle and neuronal capillaries. Thus, red cell Hbs in almost all vertebrates have evolved to have very high rates of $\mathrm{O}_{2}$ association and dissociation, and almost all have relatively high $\mathrm{P}_{50}$ values $\geq \sim 20 \mu M$ or $12 \mathrm{~mm} \mathrm{Hg}$ under physiological conditions.

A similar situation occurs for mammalian Mbs, which act as $\mathrm{O}_{2}$ storage and release proteins in striated muscle. The rates of uptake are rapid $\left(\mathrm{k}_{\mathrm{O} 2}^{\prime} \geq \sim 15 \times 10^{6} M^{-1} \mathrm{~s}^{-1}\right)$ when $\mathrm{O}_{2}$ is delivered to myocytes during blood flow, and release to mitochondria cytochrome oxidase is also very rapid $\left(\mathrm{k}_{\mathrm{O} 2} \geq\right.$ $\sim 15 \mathrm{~s}^{-1}$ ) during contraction when no blood flow can occur. The ratio of these rate constants $\left(\mathrm{P}_{50} \approx 1 \mu \mathrm{M}\right.$ or $\left.0.6 \mathrm{~mm} \mathrm{Hg}\right)$ is crucial in order for the $\mathrm{Mb}$ to pick up $\mathrm{O}_{2}$ from lower affinity $\mathrm{Hb}$ in blood $\left(\mathrm{P}_{50} \approx 10-20 \mu M\right)$, but still small enough to release the $\mathrm{O}_{2}$ to mitochondrial cytochrome c oxidase, which has a $\mathrm{K}_{\mathrm{m}} \leq 0.1 \mu M$. 


\section{Electrostatic Stabilization of Bound $\mathrm{O}_{2}$}

As described above, the absolute $\mathrm{O}_{2}$ affinities of $\mathrm{Hb}$ and $\mathrm{Mb}$ are crucial to their physiological function both in terms of fluxes of $\mathrm{O}_{2}$ across blood vessel walls and in terms of storing $\mathrm{O}_{2}$ for release to mitochondrial cytochrome c oxidase during respiration. The protein portions of these globins play a crucial role in regulating the absolute affinities of the heme iron atom for the diatomic gases $\mathrm{NO}, \mathrm{CO}$, and $\mathrm{O}_{2}$ and for discrimination between them. For simple pentacoordinate ferrous model heme compounds in organic solvents, the overall association equilibrium constants for $\mathrm{NO}, \mathrm{CO}$, and $\mathrm{O}_{2}$ are on the order of $\sim 10^{12}, 10^{8}$, and $10^{4} M^{-1}(65,67,81)$. The resultant $\mathrm{P}_{50}$ or $\mathrm{K}_{\text {dissociation }}$ for $\mathrm{O}_{2}$ is too high ( $\geq 100 \mu M$ or $60 \mathrm{~mm} \mathrm{Hg}$ ) to allow efficient uptake from air, and autoxidation to the ferric forms is too rapid to allow formation of a stable oxygenated complex. In addition, the affinity of these model heme compounds for $\mathrm{CO}$ is $\sim 10,000$ times greater than for $\mathrm{O}_{2}$. As a result, $\mathrm{CO}$ produced internally by heme oxidation or present in the environment would effectively displace any $\mathrm{O}_{2}$ that did bind, making $\mathrm{CO}$ highly toxic even at very low levels. Thus, there is strong evolutionary pressure for globins to evolve mechanisms for increasing $\mathrm{O}_{2}$ affinity, discriminating in favor of $\mathrm{O}_{2}$ over $\mathrm{CO}$, and dramatically reducing autoxidation rates to allow efficient $\mathrm{O}_{2}$ transport and storage. Over the past 30 years, large libraries of recombinant $\mathrm{Mb}$ and $\mathrm{Hb}$ mutants were constructed to examine these processes.

Ligand binding to the ferrous form of $\mathrm{Mb}$ involves at least four distinct processes, which are shown in Figure 5, and this basic mechanism also applies to the reduced subunits of all animal and plant $\mathrm{Hbs}$. The first step requires the displacement of water molecules that are held in the distal pocket by hy- drogen bonding to polar residues. In the case of sperm whale $\mathrm{Mb}(\mathrm{SwMb})$, a water molecule is found $2.7 \AA$ away from His64(E7) in deoxygenated crystals and represented by the blue sphere in the upper left-hand panel in Figure 5 (83). The electron density observed at room temperature suggests an occupancy of roughly $80 \%$. Diatomic ligands cannot enter the active site if this water molecule is present. The second step involves movement of a diatomic ligand into the empty volume of the distal pocket to form a "caged" complex in which the diatomic gas is sequestered in the protein close to the sixth coordination position of the heme iron atom in the center of the porphyrin ring. This transient intermediate is represented by

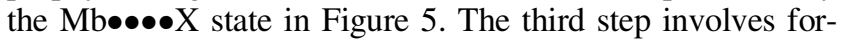
mation of the covalent bond with the iron atom to generate the bound state, $\mathrm{MbX}$, and is the major driving force for the overall binding process. The last step involves minor rearrangements that lead to electrostatic stabilization of the bound ligand, which in the case of mammalian Mbs and $\mathrm{Hb}$ subunits involves formation of a hydrogen bond donated by $\mathrm{H}-\mathrm{N} \varepsilon$ of His(E7), as shown in the right-hand panel in Figure 5.

Using this mechanism, we derived an expression for the overall association equilibrium constant, which is given below, using the equilibrium constants defined in Figure $5(67,68)$ :

$$
\mathrm{K}_{\text {association }}=\left(\frac{1}{1+\mathrm{K}_{\mathrm{H}_{2} \mathrm{O}}\left[\mathrm{H}_{2} \mathrm{O}\right]}\right) \mathrm{K}_{\text {entry }} \mathrm{K}_{\text {bond }}\left(1+\mathrm{K}_{\text {stabilization }}\right)
$$

The four terms in Equation 5 provide explanations for what determines overall ligand affinity. The $1 /\left(1+\mathrm{K}_{\mathrm{H} 2 \mathrm{O}}\left[\mathrm{H}_{2} \mathrm{O}\right]\right)$ term represents the fraction of empty distal pockets in deoxyMb, which $\approx 0.2$ based on the observed fractional
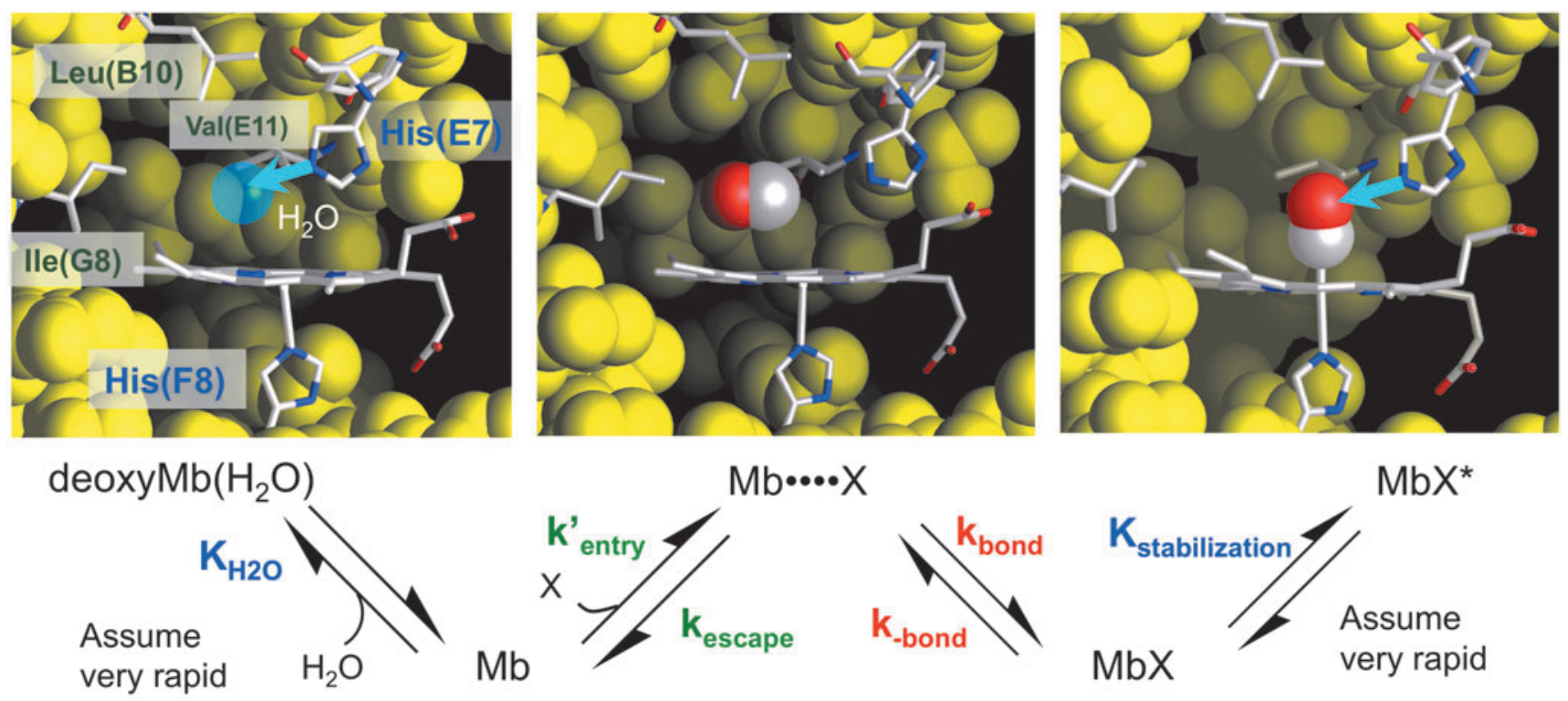

$$
\text { Green-apolar interactions } \quad \mathrm{K}_{\text {entry }}=\frac{\mathbf{k}_{\text {entry }}^{\prime}}{\mathbf{k}_{\text {escape }}} \mathrm{K}_{\text {bond }}=\frac{\mathbf{k}_{\text {bond }}^{\prime}}{\mathbf{k}_{\text {-bond }}} \quad \begin{aligned}
& \text { Blue }- \text { polar interactions } \\
& \text { Red }- \text { iron coordination }
\end{aligned}
$$

FIG. 5. General mechanism for ligand binding to Hbs and Mbs based on the structures of deoxyMb (left top panel), the initial photodissociated MbCO product (middle top panel) and MbCO (right top panel) and libraries of recombinant SwMb mutants as described in Olson and Ghosh (65), Olson and Phillips (67), and Olson et al. (68). Mb, myoglobin; SwMb, sperm whale Mb. 
occupancies $(\sim 0.8)$ of distal pocket water in crystal structures of sperm whale deoxyMb. This factor is independent of the size and chemistry of the ligand molecule. $\mathrm{K}_{\text {entry }}$ represents the bimolecular association equilibrium constant for nonspecific binding in the distal cavity, which is driven by a hydrophobic effect because the diatomic gases are apolar. The value of $\mathrm{K}_{\text {entry }}$ is on the order of $1 \mathrm{M}^{-1}$ and the same for all three diatomic gases, which have approximately the same size, polarity, and solubility in water (1-2 $\mathrm{m} M$ at $1 \mathrm{~atm})$. Thus, there is no discrimination between the ligands for the first two steps.

The overall binding reaction is driven by iron-ligand bond formation, where $\mathrm{K}_{\mathrm{bond}}$ is on the order of $10^{12}, 10^{8}$, and $10^{4}$ for internal $\mathrm{NO}, \mathrm{CO}$, and $\mathrm{O}_{2}$ coordination to the heme iron atom and reflects the intrinsic chemical differences between the ligands. The absolute value of $\mathrm{K}_{\text {bond }}$ can be altered markedly by steric hindrance from large amino acids on the distal side of the heme ring and by steric restraints on the proximal side that inhibit in-plane movement of the ironHis(F8) complex. These proximal constraints can be due to conformations that restrict movement of the F-helix as in human $\mathrm{Hb}$ or an eclipsed orientation of the proximal imidazole ring with respect to pyrrole $\mathrm{N}$ atoms, both of which lower ligand affinity.

Distal steric hindrance and proximal constraints cause roughly equal decreases in the affinities of all three diatomic gases. There is virtually no discrimination between the linear versus bent geometries of the $\mathrm{Fe}-\mathrm{O}_{2}$ versus $\mathrm{Fe}-\mathrm{CO}$ complexes even when larger amino acid side chains are inserted at the four key positions (CD1, B10, E7, and E11) adjacent to the bound ligand. Larger distal side chains do decrease the affinities for $\mathrm{NO}, \mathrm{CO}$, and $\mathrm{O}_{2}$ markedly, but by the same amount $(67,68)$. However, as expected, steric hindrance in the distal portion of the heme pocket does dramatically discriminate between isocyanide ligands with differing sizes and shapes $(7,8,99)$.

The last term in Equation 5, $\left(1+\mathrm{K}_{\text {stabilization }}\right)$, represents the extent of electrostatic stabilization of the bound ligand and does differ dramatically between the bound irondiatomic ligand complexes. The $\mathrm{Fe}(\mathrm{II})-\mathrm{O}_{2}$ complex is highly polar due to partial oxidation of the iron atom leading to a significant partial negative charge on the second bound $\mathrm{O}$ atom (65). This partial charge allows bound $\mathrm{O}_{2}$ to accept a strong hydrogen bond from $\mathrm{H}-\mathrm{N}_{\varepsilon}$ of $\mathrm{His}(\mathrm{E} 7)$ or $\mathrm{Gln}(\mathrm{E} 7)$. In contrast, the $\mathrm{Fe}$ (II)-CO and $\mathrm{Fe}(\mathrm{II})-\mathrm{NO}$ complexes are apolar and only weakly stabilized by hydrogen bonding interactions. The extent of this stabilization can be measured quantitatively by examining the effects of mutations in the distal pocket on ligand dissociation rate constants.

If water binding in the first step and hydrogen bonding in the last step of the mechanism shown in Figure 5 are assumed to be very fast, expressions for the overall bimolecular association and unimolecular dissociation rate constants $\left(\mathrm{k}_{\text {association }}^{\prime}, \mathrm{k}_{\text {dissociation }}\right)$ can be derived by assuming a steadystate approximation for the transient $\mathrm{Mb} \bullet \bullet \bullet X$ intermediate $(68,88)$.

$$
\begin{aligned}
& \mathrm{k}_{\text {association }}^{\prime}=\left(\frac{1}{1+\mathrm{K}_{\mathrm{H}_{2} \mathrm{O}}\left[\mathrm{H}_{2} \mathrm{O}\right]}\right) \mathrm{k}_{\text {entry }}^{\prime}\left(\frac{\mathrm{k}_{\text {bond }}}{\mathrm{k}_{\text {bond }}+\mathrm{k}_{\text {escape }}}\right) \\
& \mathrm{k}_{\text {dissociation }}=\left(\frac{\mathrm{k}_{\text {escape }}}{\mathrm{k}_{\text {bond }}+\mathrm{k}_{\text {escape }}}\right) \mathrm{k}_{- \text {bond }}\left(\frac{1}{1+\mathrm{K}_{\text {stabilization }}}\right)
\end{aligned}
$$

The expressions in Equation 6 show that the overall association rate constant is directly proportional to the fraction of water-free or empty active sites in deoxyMb, whereas the dissociation rate constant is directly proportional to the fraction of bound ligand molecules that are not electrostatically stabilized by the polar residues in the active site [i.e., 1/ $\left.\left(1+\mathrm{K}_{\text {stablization }}\right)\right]$. Thus, the most direct way to measure the extent of preferential electrostatic stabilization of bound $\mathrm{O}_{2}$ is to compare the oxygen dissociation rate constant of the native protein with those for variants in which the distal His(E7) has been replaced by an apolar amino acid of comparable size.

In 1999, George Phillips' and my group correlated the overall rates of ligand dissociation from a library of 29 different mammalian $\mathrm{Mb}$ variants with electrostatic fields near the bound ligand atoms that were calculated from their corresponding high-resolution crystal structures (81). The results are shown in Figure 6 and define the extent of preferential electrostatic stabilization of bound $\mathrm{O}_{2}$ quantitatively. In principle, we could use the expression for $\mathrm{k}_{\mathrm{dissociation}}$ in Equation 6 and then attempt to determine the values of $\mathrm{k}_{\text {escape }}, \mathrm{k}_{\text {bond }}$, and $\mathrm{k}_{\text {-bond }}$ from global analyses of rapid mixing and ultrafast laser photolysis experiments for each variant to try to estimate

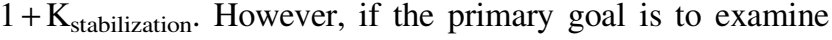

FIG. 6. Preferential electrostatic stabilization of bound $\mathrm{O}_{2}$ in SwMb as measured by decreases in the $\mathrm{O}_{2}$ dissociation rate constants of a library of 29 distal pocket mutants.
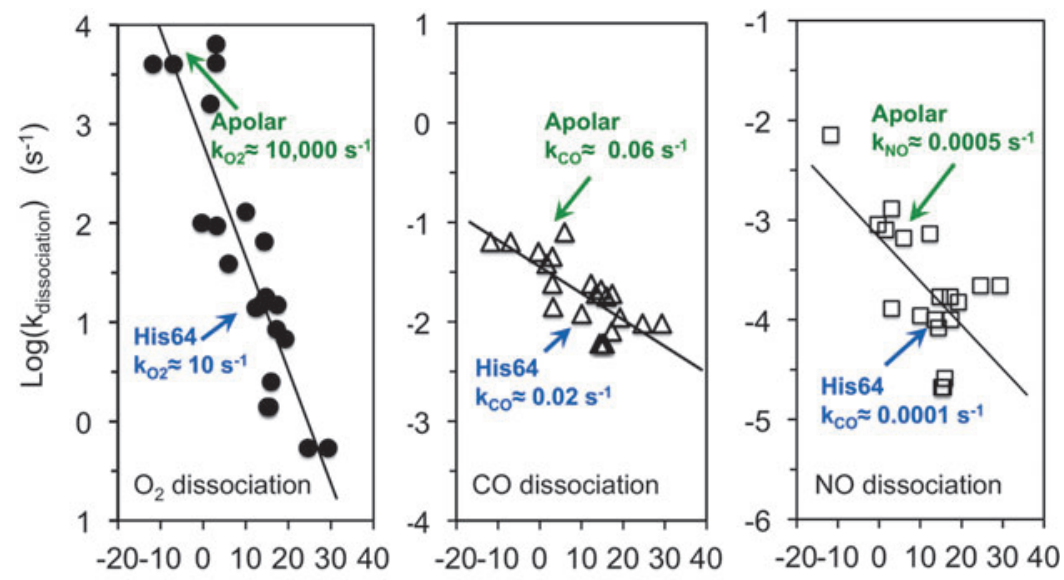

Electrostatic Potential at the $\mathrm{O}$ atom of the bound ligand $(\mathrm{kcal} / \mathrm{mol})$ 
stabilization in the native protein, then replacement of the distal histidine with an apolar amino acid of similar size allows a simpler, experimental determination of the extent of stabilization. The observed rate of ligand dissociation without polar interactions should be given by just the $\left(\mathrm{k}_{\text {escape }} /\left(\mathrm{k}_{\text {escape }}+\right.\right.$ $\left.\left.\mathrm{k}_{\text {bond }}\right)\right) \mathrm{k}_{\text {-bond }}$ term in Equation 6 , which is the internal rate of Fe-ligand bond dissociation times the fraction of internal dissociated ligands that escape the distal pocket. Thus, the $\mathrm{k}_{\text {dis- }}$ sociation for wild-type $\mathrm{Mb}$ should equal the $\mathrm{k}_{\text {dissociation }}$ for the apolar variant reduced by the extent of electrostatic stabilization due to His(E7).

$$
\mathrm{k}_{\text {dissociation }}(\text { wild-type })=\mathrm{k}_{\text {dissociation }}(\text { apolar })\left(\frac{1}{1+\mathrm{K}_{\text {stabilization }}}\right)
$$

Based on Equation 7, the extent of electrostatic stabilization is given by the ratio $\mathrm{k}_{\text {dissociation }}\left(\right.$ apolar) $/ \mathrm{k}_{\text {dissociation }}$ (polar or wild-type).

As shown in Figure 6, there is a strong linear correlation between the $\log \left(\mathrm{k}_{\text {dissociation }}\right)$ and the computed electrostatic field at the second bound ligand atom. The details of these calculations are given in Phillips et al. (81). Positive fields are due to single or multiple $\mathrm{H}$ atom donors (i.e., His, Gln, Asn) and positive multipoles (Phe) in the active site. Neutral fields indicate an apolar pocket, and negative fields reflect nonbonded electrons of $\mathrm{O}$ atoms pointing toward the bound ligand (i.e., Thr, Tyr). These data show unambiguously that bound $\mathrm{O}_{2}$ is markedly affected by electrostatic fields, with $\mathrm{k}_{\mathrm{O} 2}$ values ranging from roughly $10,000 \mathrm{~s}^{-1}$ to $\leq 0.5 \mathrm{~s}^{-1}$, where multiple H-bond donors [His(E7), Asn(E11)] are present. The value of $\left(1+\mathrm{K}_{\text {stabilization }}\right)$ in wild-type $\mathrm{MbO}_{2}$ with His64(E7) is roughly 1000 based on the values shown in Figure 6, left panel. Significantly less dependence is seen for both $\mathrm{CO}$ and $\mathrm{NO}$ dissociation. In the case of $\mathrm{MbCO}$, the rate of dissociation is on the order of $0.06 \mathrm{~s}^{-1}$ for apolar variants and $0.02 \mathrm{~s}^{-1}$ for wild-type $\mathrm{Mb}$, indicating that $\mathrm{H}$-bonding from His64(E7) only stabilizes bound $\mathrm{CO}$ by a factor of $\sim 3$. In the case of $\mathrm{NO}$, the extent of stabilization is roughly fivefold (i.e., $\mathrm{k}_{\mathrm{NO}}($ apolar $) / \mathrm{k}_{\mathrm{NO}}$ (wild-type $)=0.0005 \mathrm{~s}^{-1} / 0.0001 \mathrm{~s}^{-1}$ ).

The data in Figure 6 show that positive electrostatic fields stabilize bound ligands, with the greatest decrease in $\mathrm{k}_{\text {dissociation }}$ occurring for the polar $\mathrm{Fe}^{\delta(+)}-\mathrm{O}_{2}{ }^{\delta(-)}$ complex. The net effect on overall ligand affinity, $\mathrm{K}_{\text {association, is smaller }}$ because as shown in Figure 6 and Equation 5, there is also a nonspecific inhibitory effect of having a polar amino acid in the active site due to stabilization of a distal pocket water molecule in the deoxyMb state. The net effect of introducing a polar amino acid into the distal pocket is determined by the ratio $\left(1+\mathrm{K}_{\text {stabilization }}\right) /\left(1+\mathrm{K}_{\mathrm{H} 2 \mathrm{O}}\left[\mathrm{H}_{2} \mathrm{O}\right]\right)$.

The inhibitory factor, $1+\mathrm{K}_{\mathrm{H} 2 \mathrm{O}}\left[\mathrm{H}_{2} \mathrm{O}\right]$, can be determined from either (i) the water occupancy observed in room temperature crystal structures of deoxyMb or (ii) the effects of replacement of His64(E7) with apolar amino acids on the association rate constants, which are proportional to the fraction of empty distal pockets (Eq. 6). For mammalian Mbs, the value of $1+\mathrm{K}_{\mathrm{H} 2 \mathrm{O}}\left[\mathrm{H}_{2} \mathrm{O}\right]$ is roughly 5 [i.e., $80 \%$ water occupancy in the deoxyMb structures and 5-10-fold increases in $\mathrm{k}_{\text {association }}$ when His(E7) is replaced with Leu, Ile, and Phe $(67,81)]$. This value for $1+\mathrm{K}_{\mathrm{H} 2 \mathrm{O}}\left[\mathrm{H}_{2} \mathrm{O}\right]$ allows a quantitative evaluation of the role of the distal histidine in discriminating in favor of $\mathrm{O}_{2}$ binding compared with either $\mathrm{CO}$ or $\mathrm{NO}$ binding. The net change in $\mathrm{O}_{2}$ affinity due to electrostatic interactions with $\mathrm{His}(\mathrm{E} 7)$ is $\left(1+\mathrm{K}_{\text {stabilization }}\right) /$ $\left(1+\mathrm{K}_{\mathrm{H} 2 \mathrm{O}}\left[\mathrm{H}_{2} \mathrm{O}\right]\right) \approx 1000 / 5$, a 200 -fold increase in $\mathrm{K}_{\text {association }}$. In the case of $\mathrm{CO}$, the distal His(E7) causes a small net decrease in affinity of $\sim 0.5$ because the inhibitory effect of the distal pocket water in deoxyMb is greater than stabilization of the bound ligand. In the case of NO, the stabilization effect is roughly equal to the inhibitory effect, and there is no net change in overall affinity between variants with and without a distal histidine.

Favorable electrostatic interactions with polar amino acids in the distal pocket also play a crucial role in inhibiting autoxidation of $\mathrm{MbO}_{2}$ and $\mathrm{HbO}_{2}$ complexes. In the early 1990s, we used our large library of mammalian Mb variants to show that autoxidation occurs by two mechanisms (13). At high $\left[\mathrm{O}_{2}\right]$, autoxidation occurs by protonation of bound $\mathrm{O}_{2}$ and direct dissociation of $\mathrm{HO}_{2} \bullet$. In the absence of the distal histidine, this process is fast $\left(\mathrm{k}_{\mathrm{ox}} \approx\right.$ $10 \mathrm{~h}^{-1}$ or $\mathrm{t}_{1 / 2} \approx 4 \mathrm{~min}$ at $37^{\circ} \mathrm{C}, \mathrm{pH} 7$ for apolar E7 mutants of $\mathrm{SwMb}$ ) because the extent of protonation of the $\mathrm{Fe}^{\delta(+)}$ $\mathrm{O}_{2}{ }^{\delta(-)}$ is fairly high $\left(\mathrm{pK}_{\mathrm{a}} \approx 6\right)$. When a strong hydrogen bond is donated to the bound $\mathrm{O}_{2}$ by His(E7), protonation is dramatically inhibited $\left(\mathrm{pK}_{\mathrm{a}} \leq 4\right)$ and the rate of autoxidation decreases to $0.05 \mathrm{~h}^{-1}$ with a $\mathrm{t}_{1 / 2} \approx 14 \mathrm{~h}$ or $840 \mathrm{~min}$ (13). Thus, electrostatic stabilization of bound $\mathrm{O}_{2}$ reduces autoxidation roughly 200 -fold at high $\left[\mathrm{O}_{2}\right]$, which is roughly the same extent that it increases $\mathrm{O}_{2}$ affinity.

At low $\left[\mathrm{O}_{2}\right]$, near or below the $\mathrm{K}_{\mathrm{d}}$ or $\mathrm{P}_{50}$ of the globin sample, the rate of autoxidation occurs by an outer sphere mechanism. In this case, solvent $\mathrm{O}_{2}$ reacts indirectly with a deoxygenated ferrous heme group that contains a weakly bound sixth ligand (water, azide, and cyanide) that favors oxidation to the ferric state (13). The rate of this autoxidation process shows a complex bell-shaped dependence on $\left[\mathrm{O}_{2}\right]$ with a maximum rate at the $\mathrm{P}_{50}$ of the $\mathrm{MbO}_{2}$ or $\mathrm{HbO}_{2}$ variant. The rate of this outer-sphere mechanism decreases to 0 at both low and very high $\left[\mathrm{O}_{2}\right]$ because it requires the reaction of the deoxygenated protein with free dioxygen. Under hypoxic conditions, there is no $\mathrm{O}_{2}$ available, and at high $\mathrm{O}_{2}$, the $\mathrm{Hb}$ or $\mathrm{Mb}$ is fully saturated and no deoxyMb or deoxyHb is available. In this case, stabilization of bound $\mathrm{O}_{2}$ by favorable electrostatic interactions with the distal histidine lowers the $\mathrm{P}_{50}$ of the sample, which decreases the rate of autoxidation under normoxic conditions by decreasing the amount of unliganded protein available for the outer sphere oxidation process.

Thus, it is clear that most globins evolved to have hydrogen bond donors in their active sites to discriminate in favor of $\mathrm{O}_{2}$ binding over $\mathrm{CO}$ (and $\mathrm{NO}$ ) and to greatly inhibit autoxidation. In the case of mammalian Mbs and $\mathrm{Hbs}$, the key residue is at the E7 helical position, which is almost always a His (or in rare cases a Gln) with hydrogen bond donation from the $\mathrm{H}-\mathrm{N}_{\varepsilon}$ atoms. In other animal and bacterial Hbs, multiple hydrogen bond donors can be present to increase $\mathrm{O}_{2}$ affinity to values equal to or greater than those for $\mathrm{CO}\left(\mathrm{P}_{50} \leq 0.01 \mu M\right.$ or $\left.\leq 0.006 \mathrm{~mm} \mathrm{Hg}\right)$ and effectively prevent any oxidation without the addition of oxidizing agents $(22,65)$. Some of these proteins appear to function as $\mathrm{O}_{2}$ scavengers, and, in most cases, the observed properties can be explained by computing electrostatic fields adjacent to the bound ligand atoms as was done for the mammalian Mbs in Figure 6. 


\section{Baseball Glove Model for $\mathrm{O}_{2}$ Entry and Capture}

As described in the first section of this review, $\mathrm{O}_{2}$ uptake and release by red cells flowing through capillaries are limited primarily by external diffusion processes, which occur on $\mu \mathrm{m}$ distance scales adjacent to the erythrocyte membrane and across the vessel walls. The rates of chemical reaction with the intracellular $\mathrm{Hb}$ and muscle $\mathrm{Mb}$ evolved to be much faster in order not to limit transport and storage under physiological conditions. With the development of recombinant $\mathrm{Mb}$ and $\mathrm{Hb}$ expression systems and ultrafast laser photolysis methods in the late 1980s, we began to examine the pathways for ligand movement in these proteins on much shorter distance and timescales and to assign specific values to the rate constants for entry, escape, and bond formation shown in the scheme in Figure 5.

These assignments require combined measurements and analyses of overall association rate constants on ms to $\mu$ s timescales and of the ultrafast internal rate parameters that are measured on picosecond to nanosecond timescales $(68,88,95)$. Immediately after a short laser pulse ( $\leq 5 \mathrm{~ns})$, the bound ligand is photodissociated into an initial geminate state in which the Fe coordination bond is broken, but the ligand is still "caged" or sequestered near the heme group by amino acid side chains in

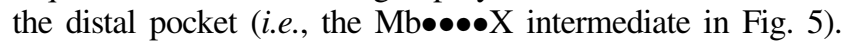
From this position, the ligand can either escape from the protein at a rate, $\mathrm{k}_{\text {escape }}$, or rebind geminately at a rate, $\mathrm{k}_{\text {bond }}$, forming a bond between the same ligand and $\mathrm{Fe}$ (i.e., a geminate pair).

The value of $\mathrm{k}_{\text {bond }}$ depends on the reactivity of the ligand molecule ( $\mathrm{NO}>>\mathrm{O}_{2}>>\mathrm{CO}$ ), the ease iron movement back into the plane of the porphyrin ring, and the steric accessibility of the iron atom on the distal side of the porphyrin ring. However, $\mathrm{k}_{\text {bond }}$ is little affected by electrostatic fields. The rate of ligand escape is roughly independent of the nature of the diatomic ligand because $\mathrm{NO}, \mathrm{CO}$, and $\mathrm{O}_{2}$ all have roughly the same size, but is affected by the location and shape of the exit pathway. Similarly, the bimolecular rate constant for ligand capture in the distal pocket to form the transient

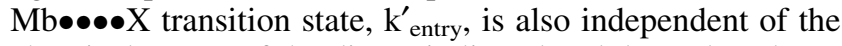
chemical nature of the diatomic ligand and depends only on the size and shape of the entry channel.

Two major ligand rebinding phases are seen in all nano- or picosecond laser photolysis experiments at room temperature. The first phase is very fast, unimolecular, and does not depend on the external ligand concentration. As shown in Figure 7, it represents internal ligand rebinding and escape

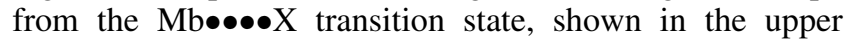
middle panel in Figure 7. The observed geminate rate for this ultrafast phase is $\mathrm{k}_{\text {gem }} \approx \mathrm{k}_{\text {bond }}+\mathrm{k}_{\text {escape }}$, and its amplitude is given by the fraction of photodissociated ligands that rebind internally, $\mathrm{F}_{\text {gem }} \approx \mathrm{k}_{\text {bond }} /\left(\mathrm{k}_{\text {bond }}+\mathrm{k}_{\text {escape }}\right)$. The second slower phase represents rebinding by ligands present in the solvent. In this case, the observed rate does depend on the external concentration of ligand and is determined by the overall bimolecular association rate constant $\mathrm{k}_{\text {association, which is de- }}^{\prime}$ fined by the upper expression in Equation 6. In this case, the photodissociated ligand does not rebind to the same iron atom because it becomes mixed with the large number of ligands in the buffer solution. As shown in Figure 7, measured values of $\mathrm{k}_{\text {gem }}, \mathrm{F}_{\text {gem }}$, and $\mathrm{k}_{\text {association }}^{\prime}$ can be used to compute the entry, escape, and bond formation rate parameters. The values of $\mathrm{k}_{\mathrm{bond}}$ and $\mathrm{k}_{\text {escape }}$ are given by $\mathrm{k}_{\mathrm{gem}} \mathrm{F}_{\text {gem }}$ and $\mathrm{k}_{\mathrm{gem}}\left(1-\mathrm{F}_{\mathrm{gem}}\right)$, respectively, and the value of $\mathrm{k}_{\text {entry }}^{\prime}$ is given by $\mathrm{k}_{\text {association }}^{\prime} / \mathrm{F}_{\text {gem. }}$.
These relationships allowed us and others to show that the values of $\mathrm{k}_{\text {bond }}$ for internal $\mathrm{NO}, \mathrm{O}_{2}$, and $\mathrm{CO}$ binding to wildtype mammalian Mbs are on the order $10^{11}, 10^{7}$, and $10^{5} \mathrm{~s}^{-1}$, respectively, at room temperature and that the bimolecular

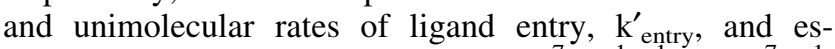
cape, $\mathrm{k}_{\text {escape }}$, are on the order of $2-3 \times 10^{7} M^{-1} \mathrm{~s}^{-1}$ and $10^{7} \mathrm{~s}^{-1}$, respectively, for all three diatomic ligands (95). These values explain why the fractional amount of geminate rebinding of NO after photolysis is effectively 1 because for this ligand the ratio of $\mathrm{k}_{\text {bond }} / \mathrm{k}_{\text {escape }}$ is $10^{4}$ and all of the photodissociated NO molecules rebind before they have time to escape. The barrier to internal NO rebinding to $\mathrm{Fe}(\mathrm{II})$ is very small because both the pentacoordinate iron atom and the ligand have unpaired electrons and are high-spin states (29). As a result, the overall association rate for NO binding can be used as an independent measure of the bimolecular rate for ligand entry because $\mathrm{k}_{\mathrm{NO}}^{\prime}=\mathrm{k}_{\text {entry }}^{\prime} \mathrm{F}_{\text {gem }} \approx \mathrm{k}_{\text {entry }}^{\prime}$, which for $\mathrm{Mb}$ is 2$3 \times 10^{7} M^{-1} \mathrm{~s}^{-1}(88,95)$. Photolysis of $\mathrm{MbCO}$ shows the opposite result, and there is almost complete escape of the $\mathrm{CO}$ into solvent after photodissociation because the ratio $\mathrm{k}_{\text {bond }} /$ $\mathrm{k}_{\text {escape }} \approx 0.01$. As a result, the $\mathrm{F}_{\text {gem }}$ values for most native MbCOs are $\leq 0.05$ at room temperature, making it difficult to determine the individual geminate parameters for this ligand. In the case of $\mathrm{MbO}_{2}$, the values of $\mathrm{k}_{\text {bond }}$ and $\mathrm{k}_{\text {escape }}$ are roughly equal and $\mathrm{F}_{\mathrm{gem}} \approx 0.5$. As a result, the individual geminate rate parameters and $\mathrm{k}_{\text {entry }}^{\prime}$ for $\mathrm{O}_{2}$ binding are readily measured under room temperature and physiological conditions.

In 1996, Quentin Gibson decided to retire from Cornell University and moved his laboratory and ns and ps laser photolysis instruments to Rice University to work directly with my group for the next seven winters. In collaboration with Steve Sligar's, Anthony Wilkinson's, and Masao Ikeda Saito's groups, we had already generated a library of well over a 100 different $\mathrm{Mb}$ variants and wondered if these mutants could be used to define the pathways for ligand movements in $\mathrm{Mb}$ after laser photolysis. At the time, many workers in the field suggested that ligands escape from the distal pocket by initial movements into the interior of the globin and then leave by multiple pathways out to solvent based on molecular dynamics simulations [for a review, see Elber (26)].

Tilton et al. (107) suggested that ligands move into the apolar cavities that are occupied by Xe atoms in crystal structures of $\mathrm{Mb}$, which were determined under high pressures ( $\geq 10 \mathrm{~atm})$ of Xe gas. The highest occupancy based on electron density is at the Xe1 site, which is a large cavity underneath the heme group (bottom middle panel, Fig. 7), and the next highest occupancy is at the $\mathrm{Xe} 4$ site, which is located on the distal side of the heme pocket, toward the interior of the globin but connected to the active site (second middle panel, Fig. 7). Initial time-resolved crystallography results suggested that a portion of photodissociated $\mathrm{CO}$ molecules move first to the Xe4 site and then to the Xe1 site (106). My graduate student Scott and Gibson (94) tested these ideas by examining geminate recombination in $\mathrm{MbO}_{2}$ variants with mutations that blocked access to or filled the Xe4 and Xe1 cavities and in samples exposed to high pressures of Xe gas.

Time courses for geminate $\mathrm{O}_{2}$ rebinding in $\mathrm{Mb}$ often show two phases. The major, more rapid phase represents rebind-

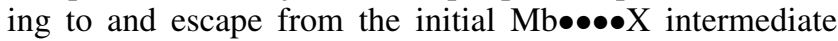
shown in Figures 6 and 7. The smaller and slower geminate phase $(\leq 30 \%)$ was thought to represent rebinding of $\mathrm{O}_{2}$ 


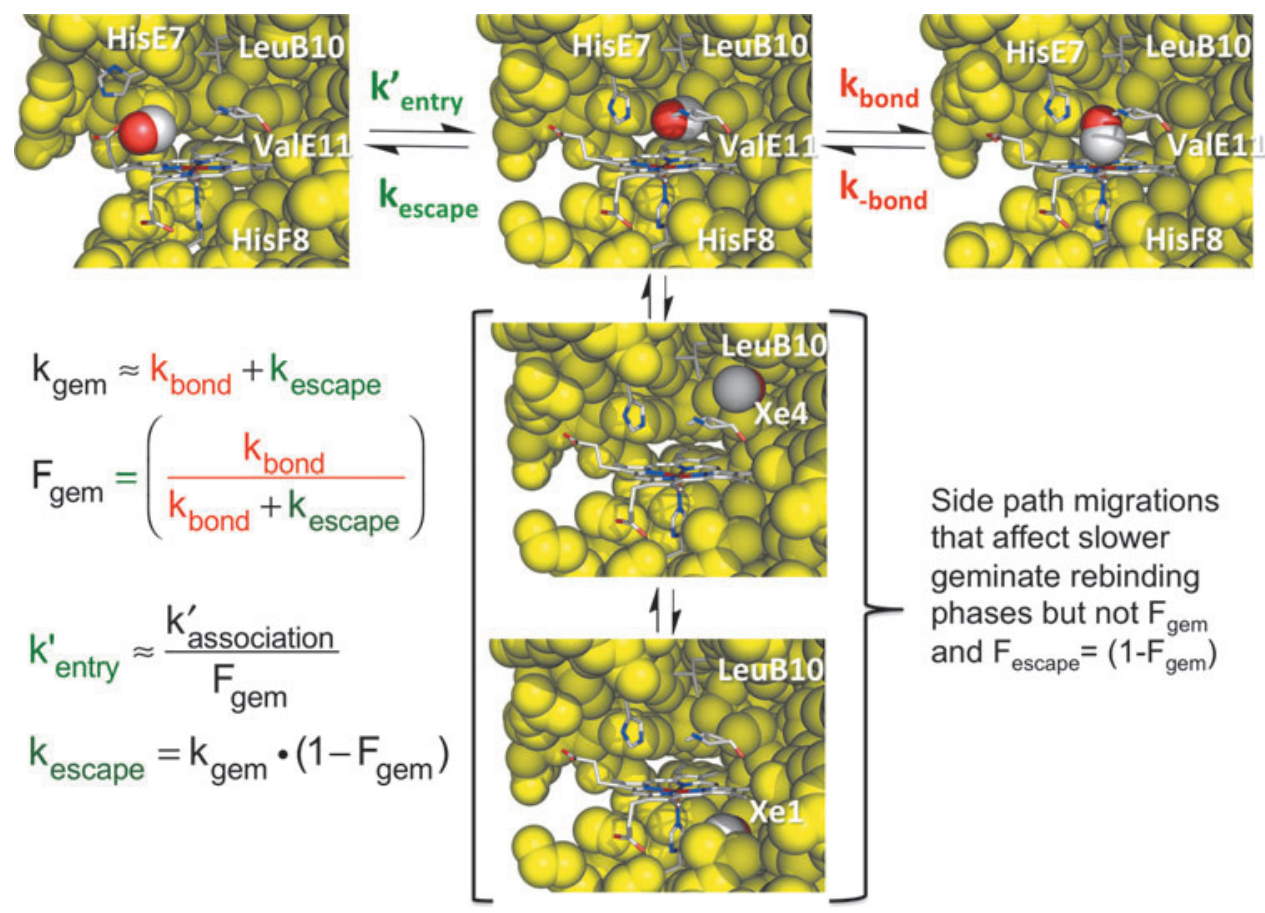

FIG. 7. Simplified mechanisms for geminate and bimolecular ligand binding to SwMb taken from Olson et al. (68), Salter et al. (88), and Scott et al. (95). The side pathway involving the $\mathrm{Xe} 1$ and $\mathrm{Xe} 4$ sites affects the number of geminate phases but not the fraction of geminate recombination, $\mathrm{F}_{\text {gem }}$. In most cases the observed data for $\mathrm{Mb}$ and $\mathrm{Hb}$ can be approximated by a single phase at room temperature, and in all cases, the rate of entry, $\mathrm{k}_{\text {entry }}^{\prime}$, can be computed from the empirically determined, $\mathrm{F}_{\text {gem }}$, and $\mathrm{k}_{\text {association }}^{\prime}$ [see Olson et al. (68), Salter et al. (88), and Scott et al. (95)]. molecules that had moved further into the protein interior, primarily into the larger Xe1 cavity. When Scott and Gibson (94) looked at the effects of mutations that either blocked movement into or filled the $\mathrm{Xe} 4$ and $\mathrm{Xe} 1$ cavities, the slower geminate recombination phase disappeared and only a single rapid phase was observed. The same result was obtained by looking at $\mathrm{O}_{2}$ geminate rebinding in the samples exposed to high enough pressures of Xe gas to fully occupy the Xe1 cavity.

These results showed that photodissociated ligands can access the interior Xe cavities, which was later confirmed by high-resolution time-resolved crystallographic studies of photodissociated MbCO crystals $(92,93,101)$. However, to me, the most remarkable result of these first studies was that mutations that filled the Xel cavity or the presence of bound Xe did not change either the overall fraction of geminate recombination $\left(\mathrm{F}_{\mathrm{gem}} \approx 0.5\right)$ or the overall bimolecular association rate constant for $\mathrm{O}_{2}$ binding $\left(\mathrm{k}_{\mathrm{O} 2}^{\prime} \approx 15 \times 10^{6} \mathrm{M}^{-1} \mathrm{~s}^{-1}\right)(95)$. The latter observation suggested the "side path" scheme for ligand recombination shown in Figure 7, which had first been proposed by Magde and colleagues (114). In this mechanism, ligands that move into the interior cavities have to return to the distal pocket to escape through a pathway created by the outward movement of the imidazole side chain of His(E7). This distal histidine or E7 gate pathway is the shortest route out of the active site and had been proposed initially by Perutz in 1969 (76) and then later by workers who examined the crystal structures of $\mathrm{Mb}$ derivatives containing large bound ligand molecules $(11,48,85,99)$, which move His(E7) outward toward the solvent (upper left panel, Fig. 7).

In the late 1990s, we developed a mutagenesis mapping approach to try to define experimentally and unambiguously the pathway for ligand entry and exit in $\mathrm{Mb}$. Our approach expanded on the work of Huang and Boxer (45) who created a library of random point mutations in human $\mathrm{Mb}$ and then screened robotically bacterial expression lysates for changes in bimolecular and geminate $\mathrm{CO}$ rebinding. They then mapped the results on the structure of $\mathrm{Mb}$ by highlighting the amino acids where mutations had the largest effects on $\mathrm{CO}$ rebinding parameters. Although most of the effects mapped to regions near the distal His(E7) gate or in the distal pocket, a significant number of changes were found far removed from the active site, and, as a result, Huang and Boxer (45) suggested that their results supported the multiple pathways and motions out of the Xe cavities that had been seen in molecular dynamics simulations.

We adopted a more labor-intensive approach and constructed large to small amino acid mutations at positions that line the pathways proposed by simulations for ligand entry and escape. The assumption is that if the amino acid side chain is on the pathway, a change from Trp or Phe to Ala or Gly should result in large increases in the rates of both entry and escape $\left(\mathrm{k}_{\text {entry }}^{\prime}\right.$ and $\mathrm{k}_{\text {escape }}$ in Figs. 6 and 7). Our approach required the following: (i) producing more than 100 different $\mathrm{Mb}$ variants in large amounts; (ii) measuring overall and geminate rates of $\mathrm{O}_{2}, \mathrm{CO}$, and $\mathrm{NO}$ binding in laser photolysis experiments to compute the $\mathrm{k}_{\text {entry }}^{\prime}$ and $\mathrm{k}_{\text {escape }}$ values; and (iii) determining the crystal structures of the key mutants to ensure that no large conformational changes occurred. The initial work for $\mathrm{Mb}$ was published in 2001 by Scott et al. (95) and then later expanded to include more positions in 2012 by Salter et al. (88).

To map the results on the Mb structure, an entry/escape rate enhancement factor, $\mathrm{R}_{\text {enhance, }}$, was defined as follows:

$$
\mathrm{R}_{\text {enhance }}=\log \left(\frac{\mathrm{k}_{\text {entry, small }}^{\prime}}{\mathrm{k}_{\text {entry, large }}^{\prime}}\right)+\log \left(\frac{\mathrm{k}_{\text {escape, small }}^{\prime}}{\mathrm{k}_{\text {escape, large }}^{\prime}}\right)
$$

Large to small mutations should increase both the entry and escape rates if they are located on the main pathway for ligand binding and give rise to large positive values for both logarithmic terms in Equation 8. Replacements at positions not on the pathway should have no effect on $\mathrm{k}_{\text {entry }}$ and $\mathrm{k}_{\text {escape }}$ 
with $\mathrm{R}_{\text {enhance }}$ values close to zero. Some mutations in the heme pocket can cause significant changes in the overall association and dissociation rate constants due to changes in the internal rate of iron-ligand bond formation, water occupancy, and electrostatic stabilization but have no effect on rates of entry and escape (see Eq. 6).

The $R_{\text {enhance }}$ values for the various amino acid positions were mapped on the $\mathrm{Mb}$ structure in the left-hand panels of Figure 8, using the following coding pattern: red spheres, $R_{\text {enhance }} \geq 1.5$ ( $>10$-fold increases in entry/escape rates); orange spheres, $1.5<\mathrm{R}_{\text {enhance }} \geq 1.0$ (between 5- and 10-fold increases); yellow spheres, $1.0<\mathrm{R}_{\text {enhance }} \geq 0.5$ (between 3 - and 5-fold increases); and gray sticks, $R_{\text {enhance }}<0.5$ (less than 2 -fold changes). In our view, the results are unambiguous; the only amino acid positions that "light up" are at the His(E7) gate pathway and in the distal pocket. No large to small replacements at positions at or near the $\mathrm{Xe} 1$ and $\mathrm{Xe} 4$ sites or along other proposed interior pathways affect the rates of entry and exit in $\mathrm{Mb}$. Similarly, the presence or absence of bound Xe has little or no effect on the rates of ligand entry and exit.

Although our initial mutagenesis map was published in 2001 (95), a large number of molecular dynamics simulation articles continued to argue strongly that (i) ligands escape through multiple pathways in the interior of the $\mathrm{Mb}$ as well as through the E7 channel and (ii) that some fraction of dissociated ligands move from the Xe pockets to the solvent phase without returning to the distal pocket $(12,26,63,87)$. We began to wonder if there was a flaw in our mutagenesis mapping strategy and looked for an $\mathrm{Hb}$ system that had a pathway for ligand entry through the interior or "back" of the globin structure. Austen Riggs at the University of Texas was kind enough to suggest that we contact Luc Moens and Sylvia Dewilde at the University of Antwerp and Martino Bolognesi at the University of Milan and help them study the kinetics of ligand binding to the neuronal mini-Hb from the Nemertean sea worm Cerebratulus lacteus (CerHb) (78). Bolognesi's group (79) had reported a crystal structure for this globin that showed the presence of an apolar channel leading from the C-terminal ends of the $\mathrm{E}$ and $\mathrm{H}$ helices through the "back" of the protein to the distal portion of the heme pocket (Fig. 8).

Together with Dewilde's group, we constructed a library of $\sim 120$ different CerHb mutants, measured both the overall association and dissociation rate constants and the geminate rebinding parameters for all these variants, and together with Bolognesi's group determined the crystal structures of a large number of these proteins $(78,80,88)$. We then used Equation 8 to map the effects of large to small replacements on $\mathrm{k}_{\text {entry }}$ and $\mathrm{k}_{\text {escape }}^{\prime}$ on the structure of CerHb and compared the results with those for SwMb, as shown in Figure 8 (88).

Again, the results are clear; ligands enter and exit $\mathrm{CerHb}$ by the interior apolar tunnel and not the E7 gate. We were able to partially close the entrance to the tunnel by Trp insertions at the $\mathrm{C}$-terminal ends of the $\mathrm{E}$ and $\mathrm{G}$ helices and to inhibit entry and exit by the binding of $\mathrm{Xe}$ atoms in the tunnel using high pressures of Xe gas (80). Interestingly, the overall rates of $\mathrm{O}_{2}$ uptake and release are almost 10-fold larger for $\mathrm{CerHb}$ even though the apolar channel is longer than the E7 gate channel in $\mathrm{Mb}$. CerHb acts as a neuronal $\mathrm{O}_{2}$ storage protein, surrounding the brain and axons of the Nemertean sea worm (112). Thus, rapid release of $\mathrm{O}_{2}$ allows high neuronal activity under hypoxic conditions on the seafloor when the worm hunts for prey $(88,112)$.

In addition to being intrinsically interesting and relevant to its physiological function, the mapping results for $\mathrm{CerHb}$ demonstrate that our mutagenesis mapping strategy can "find" an interior apolar tunnel and add strength to our conclusion that there are no such pathways in $\mathrm{Mb}$. In $\mathrm{Mb}$, the A-helix blocks any ligand movement out through the interior of the $\mathrm{Mb}$ structure, whereas it is missing in the smaller $\mathrm{CerHb}$ structure. Since the publication of our original $\mathrm{Mb}$
FIG. 8. Mutagenesis maps of the positions that are on the pathways for ligand entry and escape into and out of SwMb and CerHb. Images were adapted from Salter et al. (88). CerHb, Cerebratulus lacteus $\mathrm{Hb}$.
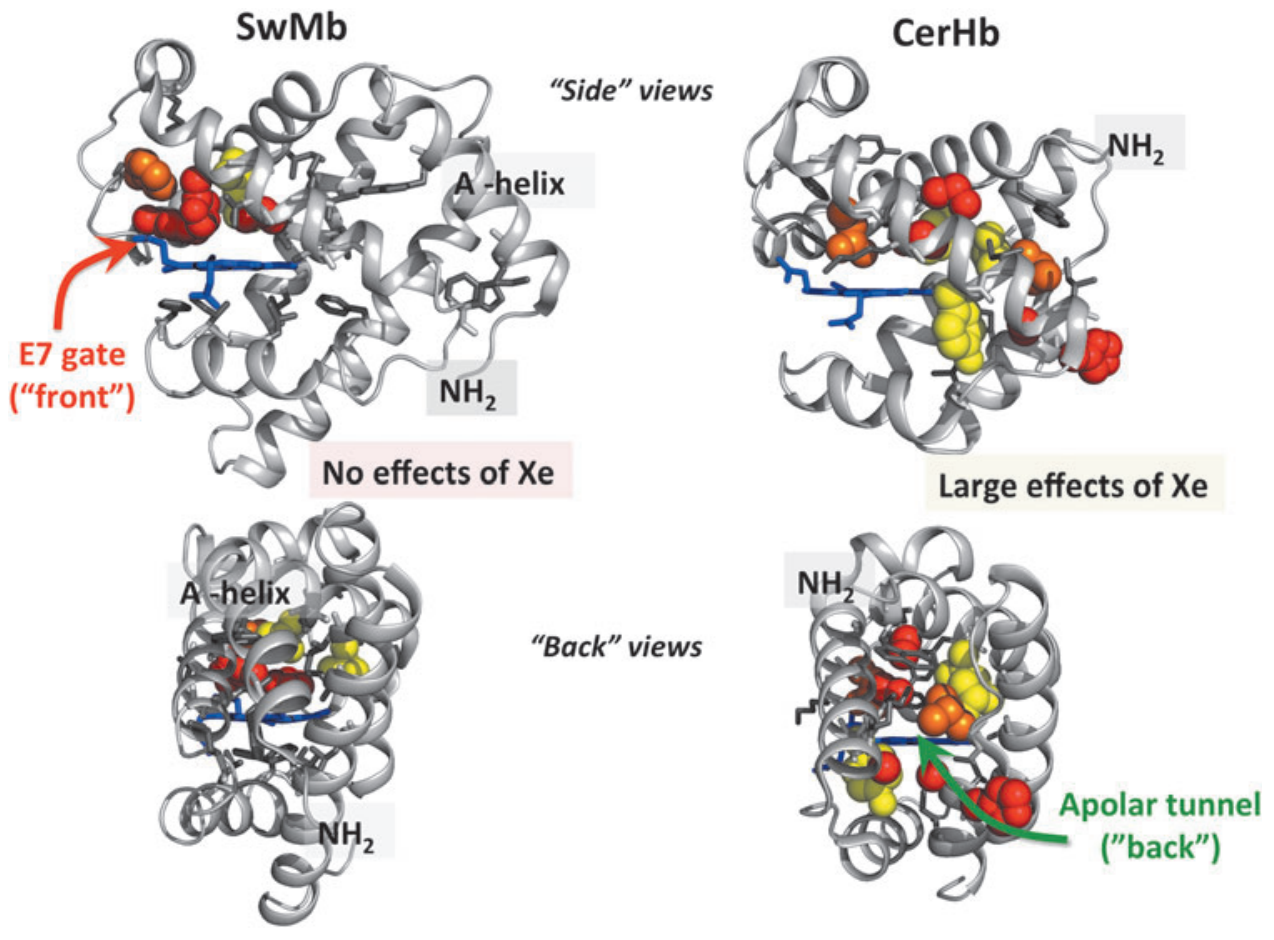
mapping study in 2001, a significant number of articles, including time-resolved crystallography experiments (92), work with larger isocyanide ligands $(7,8,99)$, molecular dynamics simulations $(9,14,15,54)$, and transition path theory (115), have been published supporting the E7 gate pathway in mammalian Mbs.

We have also carried out laser photolysis studies of libraries of human $\alpha$ and $\beta$ subunit mutants, all of which argue strongly that the E7 gate is the major pathway for ligand entry and exit in human $\mathrm{Hb}$ (4-6). Royer's group used a similar mutagenesis strategy to show that ligands enter and exit the active sites of the Scapharca inaequivalvis $\mathrm{Hb}$ dimer by a similar E7 gate even though this amino acid is very close to the dimer interface (50). Thus, the E7 channel appears to be the dominate pathway for ligand entry in most Hbs, with the only exceptions so far being apolar tunnels in $\mathrm{CerHb}$ and some truncated bacterial and plant globins [see Bustamante et al. (14, 15) and references therein]).

The E7 gate mechanism shown in Figure 8 indicates that $\mathrm{Mb}$ binds $\mathrm{O}_{2}$ in a manner analogous to catching a ball with a baseball glove. The distal histidine, like the thumb of the glove, has to move outward to create an opening to allow entry of an incoming ligand into an interior pocket that is big enough to keep $\mathrm{O}_{2}$ there until the imidazole side chain can rotate back to close the channel and sequester the ligand adjacent to the heme iron atom. Thus, the ease of movement of the distal histidine and sizes of both the E7 channel and the distal pocket play key roles in ligand capture.

The "baseball glove" model also provides a quantitative explanation for how mammalian Mbs and Hbs efficiently detoxify NO by deoxygenation, a property that is highly conserved among animal and some bacterial, fungal, and plant $\mathrm{Hbs}$ $(25,32,64,97)$. Even when $\mathrm{O}_{2}$ is bound, there is still enough room in the interior portion of the distal pocket of Mbs and $\mathrm{Hbs}$ to transiently capture NO $(21,25)$. Once inside the active site, the NO radical immediately reacts with bound $\mathrm{O}_{2}$, which has superoxide character due to partial oxidation of the iron atom. In collaboration with us, Paul Gardner's group (31) showed that both atoms of bound $\mathrm{O}_{2}$ are incorporated into the final $\mathrm{NO}_{3}{ }^{-}$ product, verifying the process as NO dioxygenation (NOD). Remarkably, the bimolecular rate of NOD, $\mathrm{k}_{\mathrm{NOD}}$, equals the observed rate of simple NO binding, $\mathrm{k}_{\mathrm{NO}}$, and the calculated values of $\mathrm{k}_{\text {entry }}^{\prime}$ for all the ferrous $\mathrm{Mb}$ variants we have examined. Thus, even when $\mathrm{O}_{2}$ is bound, $\mathrm{NO}$ enters the protein through the E7 channel shown in Figures 7 and 8. We used this mechanism to successfully engineer recombinant hemoglobin (rhB)-based oxygen carriers (rHBOCs) with reduced rates of NOD by filling the interior of the distal pocket with large aromatic amino acids at the B10, E11, and G8 positions, and these crosslinked rHBOCs showed little or no hypertensive side effects due to endothelial NO scavenging when administered to animals in transfusion experiments $(20,21,64)$.

\section{Hb Assembly and Molten Globules}

During the construction and expression of libraries of recombinant $\mathrm{Hbs}$ and Mbs, we became very interested in determining the structural factors that govern (i) resistance to denaturation to engineer more stable globins, both for our experiments and for potential HBOCs; and (ii) holoprotein expression in bacteria to increase our production yields of recombinant $\mathrm{Hbs}$ and $\mathrm{Mbs}$. The latter process is also relevant for understanding $\mathrm{Hb}$ assembly during erythropoiesis and evaluating hemoglobinopathies associated with differential expression of $\alpha$ and $\beta$ subunits, inefficient assembly, and globin instability.

A comparison of the mechanisms for $\mathrm{Mb}$ and $\mathrm{Hb}$ assembly is shown in Figure 9. The two-step pathway for apoMb folding was established by Baldwin, Barrick, Hughson, and Wright $(1,2,46,47)$ in the early 1990 s and then verified in extensive mutagenesis studies over the next 25 years $(23,27$,

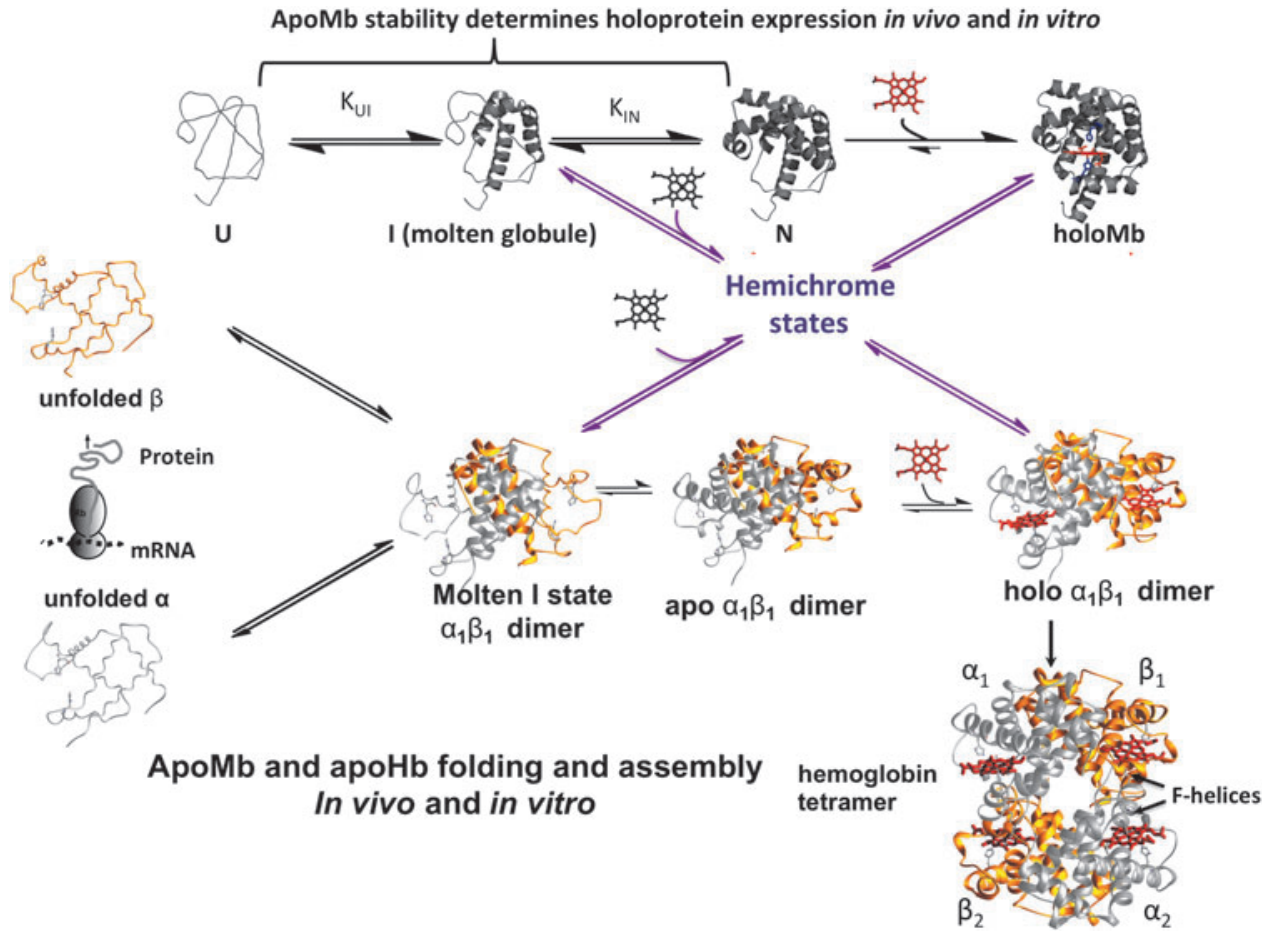

FIG. 9. Comparisons of mechanisms for $\mathrm{Mb}$ and Hb folding and assembly with heme. These schemes were taken from Samuel et al. (90, 91) and are described in the text. 
$37,49,55,58,62,98)$. During the same time period, we looked at the first steps in holoMb unfolding and denaturation, which involve autoxidation and ferriprotoporphyrin IX (hemin) dissociation. We engineered an apoMb hemin scavenging reagent by replacing the distal His(E7) with a Tyr to allow hexacoordination with the phenolic $\mathrm{O}$ atom when hemin is bound, producing a "green" ferric holoprotein with a strong absorbance peak at $610 \mathrm{~nm}$. Val(E11) was replaced with Phe to increase significantly the stability of the corresponding apoglobin double mutant (39). This reagent, H64Y/ $\mathrm{V} 68 \mathrm{~F}$ apoMb, was then used to measure the rates of hemin dissociation from our libraries of ferric oxidation state (met) $\mathrm{Mb}$ variants $(35,41)$. We also examined reversible holometMb unfolding (38) and, in 2010 (19), developed a combined analysis of apoMb and holo-metMb unfolding curves to obtain both unfolding parameters and equilibrium association constants for hemin binding to all three apoglobin unfolding states. Results from all these studies are summarized in the upper scheme in Figure 9.

ApoMb folding occurs in two major steps (23). The first involves nucleation of the $\mathrm{A}, \mathrm{H}, \mathrm{G}$ helical secondary structures in the unfolded polypeptide, $\mathrm{U}$, to form a molten globule intermediate with a native-like, interior core and a disordered or "melted" heme pocket. The second step involves folding of most of the heme pocket to generate the final native apoMb state, $\mathrm{N}$, in which only the F-helix and parts of the C-helix and CD corner are disordered. This mechanism is strongly supported by unfolding studies in which mutations that fill the heme pocket with large apolar amino acids (i.e., His(E7) to Leu or Phe, Val(E11) to Phe, Leu(B10) to Phe) greatly stabilize the N state, whereas mutations that introduce more polar residues (i.e., $\mathrm{Val}(\mathrm{E} 11)$ to Thr or Asn, $\mathrm{Leu}(\mathrm{B} 10)$ to Asn) destabilize the $\mathrm{N}$ state and facilitate formation of the molten globule intermediate $(37,91)$.

Hemin binding to native apoMb results in the final, completely folded holoprotein. Hemin binding to the molten intermediate results in a hemichrome species, which has distinct low-spin iron peaks around $\sim 540$ and $\sim 570 \mathrm{~nm}$, indicating hexacoordination with two His residues in the heme pocket (19). This molten, hemin-containing intermediate is on the pathway for folding to native aquomet-holoMb and immediately forms a fully folded pentacoordinate deoxyMb species when reduced.

The resistance of holoMb to unfolding and denaturation is governed by heme affinity and not the intrinsic stability of the apoglobin structure. The value of the heme dissociation equilibrium constant $\left(\mathrm{K}_{-\mathrm{H}}\right)$ is on the order of $10^{-14} M$ for native metMb and at least 100 times smaller for the reduced forms (i.e., deoxyMb, $\mathrm{MbO}_{2}, \mathrm{MbCO}$ where $\mathrm{K}_{-\mathrm{H}} \leq 10^{-16} M$ ) (38). As a result, much larger amounts of denaturant or lower $\mathrm{pH}$ are required to unfold the reduced forms of $\mathrm{Mb}$ and $\mathrm{Hb}$, and the limiting step for their denaturation is autoxidation.

In 1996, we showed that holo-metMb variants with poor hemin affinity denature at much lower [ $\mathrm{GdmHCl}]$ than variants with higher affinity, even when the apoMb forms of latter variants are significantly less stable (38). In most cells, metMb and metHb can be quickly reduced back to the stable ferrous forms. However, if hemin dissociates before reduction, complete denaturation occurs because apoMb is unstable at $37^{\circ} \mathrm{C}$. Thus, in practice, it is the resistance of the ferric forms of the hologlobins to hemin dissociation that determines their overall stabilities in vivo and during storage as cell-free proteins in the presence of reducing agents.
In contrast, the expression yields of holoMb correlate directly with the measured stability of the apoprotein and not at all with hemin affinity (91). In 2000, we discovered that apoMbs from deep diving mammals (whales and seals) are 100 to 600 times more stable than the apoMbs from terrestrial mammals (human, pig, etc.) (96). These results suggested an explanation for why it is easy to produce large amounts of recombinant sperm whale holoMb in Escherichia coli. In contrast, neither pig nor human $\mathrm{Mb}$ can be expressed as holoproteins in E. coli and instead have to be produced as unfolded apoproteins in inclusion bodies. Roughly 15 years later, we verified this idea by examining quantitatively the dependence of expression yield of holoMb on overall apoMb stability.

Expression of purified holoMb was measured using a wheat germ-based, in vitro translation system and a series of mutant and naturally occurring mammalian Mb genes (91). There was a direct correlation between the expression yield of the isolated holoprotein and the logarithm of the overall stability of the apoprotein. There was no correlation with the measured or estimated hemin affinity. The observed expression yield increased over 10 -fold in going from pig $\mathrm{Mb}$ to a distal pocket double mutant of dwarf sperm whale $\mathrm{Mb}$, which had an $\sim 600$-fold higher apoglobin stability constant. Similar correlations with apoglobin stability constants were observed for expression yields measured from $\mathrm{MbCO}$ spectra in E. coli cell suspensions (98) and for measured values of holoMb levels in the tissues of mammals (57).

To explain these correlations, we argued that during translation there is a competition between nonspecific, irreversible aggregation of newly synthesized unfolded apoMb polypeptides and hemin binding to the folded native apoprotein (91). The latter process is effectively first order, with a rate determined by the fraction of folded apoMb times the rate of hemin dissociation from membranes and protein carriers. The irreversible aggregation and precipitation process is second order, with a bimolecular rate that depends on the square of the absolute concentration of newly translated apoprotein times the fraction that is unfolded. At high rates of translation, aggregation of unfolded chains will increase markedly in rate due to the dependence on [total protein $\times$ fraction unfolded $]^{2}$ and make the expression process highly inefficient unless the overall stability of the monomer is so high that there are virtually no unfolded states present to react with each other. This mechanism explains the selective pressure to increase dramatically the stability of whale apoMbs, because, as described by Berenbrink and coworkers (57), these globins have to be translated in large amounts to act as $\mathrm{O}_{2}$ storage proteins in the skeletal muscle of deep diving animals.

Up until 2 years ago, no one had succeeded in examining quantitatively reversible apohemoglobin unfolding. Most investigators avoided studying adult human hemoglobin A (HbA) unfolding because of the following: (i) the instability of apoHb and its isolated chains, both of which precipitate in conventional buffers at temperatures above $10^{\circ} \mathrm{C}$; (ii) the dependence of the unfolding parameters on protein concentration due to oligomerization of $\mathrm{Hb}$ subunits; and (iii) disulfide formation between exposed cysteine thiols in both folded and unfolded states. Samuel et al. (90) solved these problems by examining $\mathrm{GdmHCl}$-induced unfolding of apoHbA as function of protein concentration in $200 \mathrm{mM}$ phosphate buffer, $\mathrm{pH} 7$ at temperatures $\leq 10^{\circ} \mathrm{C}$ in the presence of $1 \mathrm{~m} M$ dithiothreitol (DTT). 
The first key observation was that removal of hemin in the presence of DTT led to $100 \%$ formation of $\alpha_{1} \beta_{1}$ apodimers, with no evidence of tetramers or monomers. As in the case of apoMb unfolding, two phases were observed for the unfolding of these apoHb dimers. The first phase was independent of protein concentration and shifted to higher [GdmHCl] when the distal His(E7) and $\mathrm{Val}(\mathrm{E} 11)$ were replaced with Leu and Phe, respectively (90). These results indicated that, as in apoMb, the first phase represents unfolding of the heme pocket to create a molten globule intermediate, $\mathrm{I}_{\mathrm{D}}$, which, in the case of apoHb, is dimer with the $\alpha_{1} \beta_{1}$ interface still intact and stabilizing the $\mathrm{A}, \mathrm{H}$, and $\mathrm{G}$ helices. The second phase shifts to higher [GdmHCl] at higher total apoHb concentration, which is expected for a process involving dissociation of the apodimer intermediate into two unfolded monomers, $\mathrm{U}_{\mathrm{m}}$.

The second phase also shifts to higher denaturant concentration for human fetal $\mathrm{Hb}(\mathrm{HbF})$, which has a more stable $\alpha_{1} \gamma_{1}$ interface and for a recombinant $\mathrm{Hb}$ that is genetically crosslinked (90). In the latter case, removal of hemin leads to an "open" tetramer with two $\alpha_{1} \beta_{1}$ dimers covalently linked by a glycine connecting the $\mathrm{C}$-terminus of the first $\alpha$ chain to the N-terminus of the second one. Again the first step involves unimolecular unfolding of the heme pockets of all four subunits and is followed by dissociation into two unfolded monomeric $\beta$ chains and an unfolded di- $\alpha$ chain. The second phase is shifted to high [GdmHCl] because two interfaces have to be disrupted for complete dissociation of the molten intermediate tetramer. As in the case of $\mathrm{Mb}$, hemin can bind to the molten intermediate states to form hemichrome species, which can fold into native holoHb dimers and then associate to make the final $\mathrm{Hb}$ tetramer (89).

Although no systematic and quantitative study has been carried out, holoHb expression yields in vivo and in E. coli do not seem as highly dependent on apoglobin stability as was observed for $\mathrm{Mb}$. We observed little difference in the production yields of recombinant $\mathrm{HbA}$ versus $\mathrm{HbF}$ or crosslinked $\mathrm{rHbA}$ or for mutations in which the distal His(E7) and $\mathrm{Val}(\mathrm{E} 11)$ were replaced with large apolar amino acids. The simplest explanation for this result is that bimolecular association of $\alpha$ and $\beta$ subunits to form the molten dimer intermediate competes effectively against nonspecific bimolecular aggregation and precipitation of unfolded subunits. As a result, increasing the rate of translation increases equally the rates of both bimolecular processes and does not affect the efficiency of holoHbA formation. However, the individual $\alpha$ and $\beta$ genes cannot be expressed alone as holoproteins. Instead, these genes have to be transcribed and translated at equal rates to ensure rapid formation of the apo-heterodimer before the unfolded monomers begin to aggregate.

As in the case of holoMb, the resistance of $\mathrm{HbA}$ to denaturation is still governed by its rates of autoxidation and hemin dissociation. The latter two processes occur 10 to 50 times more rapidly for dimers and monomers, respectively, than for tetramers, and, as a result, the rate of denaturation of $\mathrm{Hb}$ is strongly dependent on the protein concentration $(40,59)$. Thus, inside a red cell where the $\mathrm{Hb}$ concentration is very high $(\sim 0.02 M)$, autoxidation is slow, and the red cell reduction system prevents denaturation by rereduction before any hemin can be lost. In contrast, after red cell lysis, acellular $\mathrm{Hb}$ auto-oxidizes, loses hemin, and denatures much more rapidly when it is diluted into plasma because of dimerization.
Another important conclusion from the assembly and denaturation mechanisms shown in Figure 9 is that globin function often requires a compromise in intrinsic apoglobin stability. In the cases of $\mathrm{Mb}$ and $\mathrm{Hb}$, the polar distal histidine is required to enhance selectively $\mathrm{O}_{2}$ affinity (100), inhibit autoxidation by preventing protonation of bound $\mathrm{O}_{2}$ (13), and inhibit hemin loss by hydrogen bonding to the coordinated water in the aquomet forms (41). However, when His(E7) is replaced by large apolar amino acids, the stabilities of both apoMb and apoHb are increased significantly by facilitating folding of the heme pocket and stabilization of the native apoglobin state $(19,37,90,98)$. In the case of $\mathrm{Mb}$, these mutations significantly enhance expression yields in $E$. coli and in vitro translation systems (98). The dilemma is that these mutants auto-oxidize and lose hemin rapidly, making the holoproteins highly unstable, not functional, and selected against during evolution.

\section{Conclusions}

Over the past 50 years, detailed mathematical descriptions of $\mathrm{O}_{2}$ uptake and release by red cells have been developed. These analyses provide quantitative explanations for why small erythrocytes and rapid flow are needed to reduce the size of unstirred layers adjacent to the cell surface and why small capillaries are needed to reduce the size of cell-free layers adjacent to the vessel walls.

At the molecular level, studies with libraries of mammalian $\mathrm{Mb}$ and $\mathrm{Hb}$ mutants have shown that electrostatic interactions, primarily with the distal histidine, selectively enhance $\mathrm{O}_{2}$ affinity, inhibit autoxidation, and lower rates of hemin loss. A detailed multiple-step kinetic mechanism for $\mathrm{O}_{2}$ binding to these globins has been established and is analogous to how a baseball is caught by a fielder, including opening of the glove by outward movement of the distal histidine and capture in a large, flexible interior pocket on the distal side of the porphyrin ring.

The assemblies of mammalian Mbs and Hbs show mechanisms involving first the formation of a molten intermediate with disordered or "melted" heme pockets, but well-formed, native-like secondary structures for the $\mathrm{A}, \mathrm{H}$, and $\mathrm{G}$ helices in the interior of the protein. The second step involves folding of the heme pocket and then binding of hemin to generate the native holoprotein. In the case of adult human $\mathrm{Hb}$, the initial folding intermediate is a molten globule dimer where the interior helices are stabilized by formation of a very strong $\alpha_{1} \beta_{1}$ interface. Heme binding to the fully folded $\mathrm{HbA}$ dimer then promotes formation of the $\alpha_{1} \beta_{2}$ interface generating the native tetramer, which is capable of cooperative $\mathrm{O}_{2}$ binding.

I have been fortunate to be part of the development of these biochemical mechanisms for how Mbs and Hbs are assembled and how they function in $\mathrm{O}_{2}$ storage and transport. These mechanisms are now being used to interpret how globins evolved specific properties to adapt to various environments, including high altitudes, cold temperatures, anoxia during diving, and embryonic development $(16,57,103,104)$. In all cases, the pathways for amino acid changes required consideration of effects on $\mathrm{O}_{2}$ transport function, holoprotein stability, and the efficiency of folding and assembly. These mechanisms also provide the framework for engineering globins to produce cell-free $\mathrm{O}_{2}$ carriers and storage proteins for medical and industrial purposes. Again, multiple 
properties have to be considered and optimized, including compromises between the desired function, resistance to degradation during storage or use, and production yields in E. coli or during chemical modifications $(21,34,113)$. The mechanisms for ligand binding to globins have also been used to understand the evolution of highly selective, heme proteinbased $\mathrm{NO}, \mathrm{CO}$, and $\mathrm{O}_{2}$ sensors, which are found in all kingdoms of life $(33,82,108,109)$.

\section{Acknowledgment}

I would like to thank all of my former students, fellows, technicians, staff scientists, and colleagues, who made all of this work possible.

\section{Funding Information}

The work described in this review was supported for more than 40 years by NIH grants GM035649 and HL047020, and Grant C-0612 from the Robert A. Welch Foundation, and for the last 5 years by NIH grant P01 HL110900.

\section{References}

1. Barrick D and Baldwin RL. Three-state analysis of sperm whale apomyoglobin folding. Biochemistry 32: 37903796, 1993.

2. Barrick D, Hughson FM, and Baldwin RL. Molecular mechanisms of acid denaturation. The role of histidine residues in the partial unfolding of apomyoglobin. $\mathrm{J} \mathrm{Mol}$ Biol 237: 588-601, 1994.

3. Baxley PT and Hellums JD. A simple model for simulation of oxygen transport in the microcirculation. Ann Biomed Eng 11: 401-416, 1983.

4. Birukou I, Maillett DH, Birukova A, and Olson JS. Modulating distal cavities in the alpha and beta subunits of human $\mathrm{HbA}$ reveals the primary ligand migration pathway. Biochemistry 50: 7361-7374, 2011.

5. Birukou I, Schweers RL, and Olson JS. Distal histidine stabilizes bound $\mathrm{O} 2$ and acts as a gate for ligand entry in both subunits of adult human hemoglobin. J Biol Chem 285: 8840-8854, 2010.

6. Birukou I, Soman J, and Olson JS. Blocking the gate to ligand entry in human hemoglobin. J Biol Chem 286: 10515-10529, 2011.

7. Blouin GC and Olson JS. The stretching frequencies of bound alkyl isocyanides indicate two distinct ligand orientations within the distal pocket of myoglobin. Biochemistry 49: 4968-4976, 2010.

8. Blouin GC, Schweers RL, and Olson JS. Alkyl isocyanides serve as transition state analogues for ligand entry and exit in myoglobin. Biochemistry 49: 4987-4997, 2010.

9. Boechi L, Arrar M, Marti MA, Olson JS, Roitberg AE, and Estrin DA. Hydrophobic effect drives oxygen uptake in myoglobin via histidine E7. J Biol Chem 288: 6754-6762, 2013.

10. Boland EJ, Nair PK, Lemon DD, Olson JS, and Hellums JD. An in vitro capillary system for studies on microcirculatory O2 transport. J Appl Physiol 62: 791-797, 1987.

11. Bolognesi M, Cannillo E, Ascenzi P, Giacometti GM, Merli A, and Brunori M. Reactivity of ferric Aplysia and sperm whale myoglobins towards imidazole. X-ray and binding study. J Mol Biol 158: 305-315, 1982.

12. Bossa C, Amadei A, Daidone I, Anselmi M, Vallone B, Brunori M, and Di Nola A. Molecular dynamics simula- tion of sperm whale myoglobin: effects of mutations and trapped $\mathrm{CO}$ on the structure and dynamics of cavities. Biophys J 89: 465-474, 2005.

13. Brantley RE, Jr., Smerdon SJ, Wilkinson AJ, Singleton $\mathrm{EW}$, and Olson JS. The mechanism of autooxidation of myoglobin. J Biol Chem 268: 6995-7010, 1993.

14. Bustamante JP, Abbruzzetti S, Marcelli A, Gauto D, Boechi L, Bonamore A, Boffi A, Bruno S, Feis A, Foggi $\mathrm{P}$, Estrin DA, and Viappiani C. Ligand uptake modulation by internal water molecules and hydrophobic cavities in hemoglobins. J Phys Chem B 118: 1234-1245, 2014.

15. Bustamante JP, Szretter ME, Sued M, Marti MA, Estrin DA, and Boechi L. A quantitative model for oxygen uptake and release in a family of hemeproteins. Bioinformatics 32: 1805-1813, 2016.

16. Campbell KL, Roberts JE, Watson LN, Stetefeld J, Sloan AM, Signore AV, Howatt JW, Tame JR, Rohland N, Shen TJ, Austin JJ, Hofreiter M, Ho C, Weber RE, and Cooper A. Substitutions in woolly mammoth hemoglobin confer biochemical properties adaptive for cold tolerance. Nat Genet 42: 536-540, 2010.

17. Coin JT and Olson JS. The rate of oxygen uptake by human red blood cells. J Biol Chem 254: 1178-1190, 1979.

18. Cole R, Vandegriff K, Szeri A, Savas O, and Winslow R. Targeted $\mathrm{O} 2$ delivery by blood substitutes: in vitro arteriolar simulations of first- and second-generation products. Microvasc Res 76: 169-179, 2008.

19. Culbertson DS and Olson JS. Role of heme in the unfolding and assembly of myoglobin. Biochemistry 49: 6052-6063, 2010.

20. Doherty DH, Doyle MP, Curry SR, Vali RJ, Fattor TJ, Olson JS, and Lemon DD. Rate of reaction with nitric oxide determines the hypertensive effect of cell-free hemoglobin. Nat Biotechnol 16: 672-676, 1998.

21. Dou Y, Maillett DH, Eich RF, and Olson JS. Myoglobin as a model system for designing heme protein based blood substitutes. Biophys Chem 98: 127-148, 2002.

22. Draghi F, Miele AE, Travaglini-Allocatelli C, Vallone B, Brunori M, Gibson QH, and Olson JS. Controlling ligand binding in myoglobin by mutagenesis. J Biol Chem 277: 7509-7519, 2002.

23. Dyson HJ and Wright PE. How does your protein fold? Elucidating the apomyoglobin folding pathway. Acc Chem Res 50: 105-111, 2017.

24. Eaton WA, Henry ER, Hofrichter J, Bettati S, Viappiani $\mathrm{C}$, and Mozzarelli A. Evolution of allosteric models for hemoglobin. IUBMB Life 59: 586-599, 2007.

25. Eich RF, Li T, Lemon DD, Doherty DH, Curry SR, Aitken JF, Mathews AJ, Johnson KA, Smith RD, Phillips GN, Jr., and Olson JS. Mechanism of NO-induced oxidation of myoglobin and hemoglobin. Biochemistry 35: 6976-6983, 1996.

26. Elber R. Ligand diffusion in globins: simulations versus experiment. Curr Opin Struct Biol 20: 162-167, 2010.

27. Eliezer D, Yao J, Dyson HJ, and Wright PE. Structural and dynamic characterization of partially folded states of apomyoglobin and implications for protein folding. Nat Struct Biol 5: 148-155, 1998.

28. Estep T, Bucci E, Farmer M, Greenburg G, Harrington J, Kim HW, Klein H, Mitchell P, Nemo G, Olsen K, Palmer A, Valeri CR, and Winslow R. Basic science focus on blood substitutes: a summary of the NHLBI Division of Blood Diseases and Resources Working Group Workshop, March 1, 2006. Transfusion 48: 776-782, 2008. 
29. Franzen S. Spin-dependent mechanism for diatomic ligand binding to heme. Proc Natl Acad Sci U S A 99: 16754-16759, 2002.

30. Gad-El-Hak M, Morton JB, and Kutchai H. Turbulent flow of red cells in dilute suspensions. Effect on kinetics of O2 uptake. Biophys J 18: 289-300, 1977.

31. Gardner PR, Gardner AM, Brashear WT, Suzuki T, Hvitved AN, Setchell KD, and Olson JS. Hemoglobins dioxygenate nitric oxide with high fidelity. $J$ Inorg Biochem 100: 542-550, 2006.

32. Gardner PR, Gardner AM, Martin LA, Dou Y, Li T, Olson JS, Zhu H, and Riggs AF. Nitric-oxide dioxygenase activity and function of flavohemoglobins. sensitivity to nitric oxide and carbon monoxide inhibition. $J$ Biol Chem 275: 31581-31587, 2000.

33. Gilles-Gonzalez MA and Gonzalez G. Heme-based sensors: defining characteristics, recent developments, and regulatory hypotheses. J Inorg Biochem 99: 1-22, 2005.

34. Graves PE, Henderson DP, Horstman MJ, Solomon BJ, and Olson JS. Enhancing stability and expression of recombinant human hemoglobin in E. coli: progress in the development of a recombinant HBOC source. Biochim Biophys Acta 1784: 1471-1479, 2008.

35. Hargrove MS, Barrick D, and Olson JS. The association rate constant for heme binding to globin is independent of protein structure. Biochemistry 35: 11293-11299, 1996.

36. Hargrove MS, Barry JK, Brucker EA, Berry MB, Phillips GN, Jr., Olson JS, Arredondo-Peter R, Dean JM, Klucas $\mathrm{RV}$, and Sarath G. Characterization of recombinant soybean leghemoglobin a and apolar distal histidine mutants. J Mol Biol 266: 1032-1042, 1997.

37. Hargrove MS, Krzywda S, Wilkinson AJ, Dou Y, IkedaSaito M, and Olson JS. Stability of myoglobin: a model for the folding of heme proteins. Biochemistry 33: 11767 11775, 1994.

38. Hargrove MS and Olson JS. The stability of holomyoglobin is determined by heme affinity. Biochemistry 35: 11310 11318, 1996.

39. Hargrove MS, Singleton EW, Quillin ML, Ortiz LA, Phillips GN, Jr., Olson JS, and Mathews AJ. His64(E7)$>$ Tyr apomyoglobin as a reagent for measuring rates of hemin dissociation. J Biol Chem 269: 4207-4214, 1994.

40. Hargrove MS, Whitaker T, Olson JS, Vali RJ, and Mathews AJ. Quaternary structure regulates hemin dissociation from human hemoglobin. J Biol Chem 272: 17385-17389, 1997.

41. Hargrove MS, Wilkinson AJ, and Olson JS. Structural factors governing hemin dissociation from metmyoglobin. Biochemistry 35: 11300-11309, 1996.

42. Hartridge $\mathrm{H}$ and Roughton FJ. The rate of distribution of dissolved gases between the red blood corpuscle and its fluid environment: part I. Preliminary experiments on the rate of uptake of oxygen and carbon monoxide by sheep's corpuscles. J Physiol 62: 232-242, 1927.

43. Hille R, Olson JS, and Palmer G. Spectral transitions of nitrosyl hemes during ligand binding to hemoglobin. $J$ Biol Chem 254: 12110-12120, 1979.

44. Holland RA and Forster RE. The effect of size of red cells on the kinetics of their oxygen uptake. J Gen Physiol 49: 727-742, 1966.

45. Huang $X$ and Boxer SG. Discovery of new ligand binding pathways in myoglobin by random mutagenesis. Nat Struct Biol 1: 226-229, 1994.

46. Hughson FM, Barrick D, and Baldwin RL. Probing the stability of a partly folded apomyoglobin intermediate by site-directed mutagenesis. Biochemistry 30: 4113-4118, 1991.

47. Hughson FM, Wright PE, and Baldwin RL. Structural characterization of a partly folded apomyoglobin intermediate. Science 249: 1544-1548, 1990.

48. Johnson KA, Olson JS, and Phillips GN, Jr. Structure of myoglobin-ethyl isocyanide. Histidine as a swinging door for ligand entry. J Mol Biol 207: 459-463, 1989.

49. Kay MS, Ramos CH, and Baldwin RL. Specificity of native-like interhelical hydrophobic contacts in the apomyoglobin intermediate. Proc Natl Acad Sci U S A 96: 2007-2012, 1999.

50. Knapp JE, Pahl R, Cohen J, Nichols JC, Schulten K, Gibson QH, Srajer V, and Royer WE, Jr. Ligand migration and cavities within Scapharca Dimeric HbI: studies by time-resolved crystallo-graphy, Xe binding, and computational analysis. Structure 17: 1494-1504, 2009.

51. Kreuzer F and Yahr WZ. Influence of red cell membrane on diffusion of oxygen. J Appl Physiol 15: 1117-1122, 1960.

52. Kutchai H. Role of the red cell membrane in oxygen uptake. Respir Physiol 23: 121-132, 1975.

53. Lemon DD, Nair PK, Boland EJ, Olson JS, and Hellums JD. Physiological factors affecting $\mathrm{O} 2$ transport by hemoglobin in an in vitro capillary system. $J$ Appl Physiol 62: 798-806, 1987.

54. Lucas MF and Guallar V. Single vs. multiple ligand pathways in globins: a computational view. Biochim Biophys Acta 1834: 1739-1743, 2013.

55. Luo $\mathrm{Y}$ and Baldwin RL. How Ala $\longrightarrow$ Gly mutations in different helices affect the stability of the apomyoglobin molten globule. Biochemistry 40: 5283-5289, 2001.

56. Mims MP, Porras AG, Olson JS, Noble RW, and Peterson JA. Ligand binding to heme proteins. An evaluation of distal effects. J Biol Chem 258: 14219-14232, 1983.

57. Mirceta S, Signore AV, Burns JM, Cossins AR, Campbell $\mathrm{KL}$, and Berenbrink M. Evolution of mammalian diving capacity traced by myoglobin net surface charge. Science 340: 1234192, 2013.

58. Mohana-Borges R, Goto NK, Kroon GJ, Dyson HJ, and Wright PE. Structural characterization of unfolded states of apomyoglobin using residual dipolar couplings. $J \mathrm{Mol}$ Biol 340: 1131-1142, 2004.

59. Mollan TL, Jia Y, Banerjee S, Wu G, Timothy Kreulen R, Tsai AL, Olson JS, Crumbliss AL, and Alayash AI. Redox properties of human hemoglobin in complex with fractionated dimeric and polymeric human haptoglobin. Free Radic Biol Med 69: 265-277, 2014.

60. Nelson DL and Cox MM. Lehninger Principles of Biochemistry, fifth edition. New York: W. H. Freeman and Company, 2008.

61. Nicolson P and Roughton FJ. A theoretical study of the influence of diffusion and chemical reaction velocity on the rate of exchange of carbon monoxide and oxygen between the red blood corpuscle and the surrounding fluid. Proc $R$ Soc Lond B Biol Sci 138: 241264, 1951.

62. Nishimura C, Dyson HJ, and Wright PE. Identification of native and non-native structure in kinetic folding intermediates of apomyoglobin. J Mol Biol 355: 139-156, 2006.

63. Nutt DR and Meuwly M. CO migration in native and mutant myoglobin: atomistic simulations for the understanding of protein function. Proc Natl Acad Sci U S A 101: 5998-6002, 2004. 
64. Olson JS, Foley EW, Rogge C, Tsai AL, Doyle MP, and Lemon DD. NO scavenging and the hypertensive effect of hemoglobin-based blood substitutes. Free Radic Biol Med 36: 685-697, 2004.

65. Olson JS and Ghosh A. Mammalian myoglobin as a model for understanding ligand affinities and discrimination in heme proteins. In: The Smallest Biomolecules: Perspectives on Heme-Diatomic Interactions, edited by Ghosh A. London: Elsevier, 2007, pp 3-17.

66. Olson JS and Gibson QH. The reaction of n-butyl isocyanide with human hemoglobin. II. The ligand-binding properties of the alpha and beta chains within deoxyhemoglobin. J Biol Chem 247: 1713-1726, 1972.

67. Olson JS and Phillips GN. Myoglobin discriminates between $\mathrm{O}_{2}$, NO, and $\mathrm{CO}$ by electrostatic interactions with the bound ligand. J Biol Inorg Chem 2: 544-552, 1997.

68. Olson JS, Soman J, and Phillips GN, Jr. Ligand pathways in myoglobin: a review of Trp cavity mutations. Iubmb Life 59: 552-562, 2007.

69. Page TC. Oxygen transport by hemoglobin-based blood substitutes. PhD Dissertation in Chemical Engineering, Rice University, Houston, TX, 1997. Available at: https:// scholarship.rice.edu/handle/1911/19193 (accessed October 7, 2019).

70. Page TC, Light WR, and Hellums JD. Prediction of microcirculatory oxygen transport by erythrocyte/hemoglobin solution mixtures. Microvasc Res 56: 113-126, 1998.

71. Page TC, Light WR, and Hellums JD. Oxygen transport in 10 microns artificial capillaries. Adv Exp Med Biol 471: 715-721, 1999.

72. Page TC, Light WR, McKay CB, and Hellums JD. Oxygen transport by erythrocyte/hemoglobin solution mixtures in an in vitro capillary as a model of hemoglobinbased oxygen carrier performance. Microvasc Res 55: 54 64, 1998.

73. Perutz MF. Stereochemistry of cooperative effects in haemoglobin. Nature 228: 726-739, 1970.

74. Perutz MF. Mechanisms of cooperativity and allosteric regulation in proteins. $Q$ Rev Biophys 22: 139-237, 1989.

75. Perutz MF and Lehmann H. Molecular pathology of human haemoglobin. Nature 219: 902-909, 1968.

76. Perutz MF, and Mathews FS. An x-ray study of azide methaemoglobin. J Mol Biol 21: 199-202, 1966.

77. Perutz MF, Muirhead H, Cox JM, and Goaman LC. Threedimensional Fourier synthesis of horse oxyhaemoglobin at 2.8 A resolution: the atomic model. Nature 219: 131-139, 1968.

78. Pesce A, Nardini M, Ascenzi P, Geuens E, Dewilde S, Moens L, Bolognesi M, Riggs AF, Hale A, Deng P, Nienhaus GU, Olson JS, and Nienhaus K. Thr-E11 regulates $\mathrm{O} 2$ affinity in Cerebratulus lacteus minihemoglobin. J Biol Chem 279: 33662-33672, 2004.

79. Pesce A, Nardini M, Dewilde S, Ascenzi P, Riggs AF, Yamauchi K, Geuens E, Moens L, and Bolognesi M. Crystallization and preliminary X-ray analysis of neural haemoglobin from the nemertean worm Cerebratulus lacteus. Acta Crystallogr 57: 1897-1899, 2001.

80. Pesce A, Nardini M, Dewilde S, Capece L, Marti MA, Congia S, Salter MD, Blouin GC, Estrin DA, Ascenzi P, Moens L, Bolognesi M, and Olson JS. Ligand migration in the apolar tunnel of Cerebratulus lacteus minihemoglobin. J Biol Chem 286: 5347-5358, 2011.

81. Phillips GN, Teodoro ML, Li TS, Smith B, and Olson JS. Bound $\mathrm{CO}$ is a molecular probe of electrostatic potential in the distal pocket of myoglobin. $J$ Phys Chem B 103: 8817-8829, 1999.

82. Puranik M, Nielsen SB, Youn H, Hvitved AN, Bourassa JL, Case MA, Tengroth C, Balakrishnan G, Thorsteinsson MV, Groves JT, McLendon GL, Roberts GP, Olson JS, and Spiro TG. Dynamics of carbon monoxide binding to CooA. J Biol Chem 279: 21096-21108, 2004.

83. Quillin ML, Arduini RM, Olson JS, and Phillips GN, Jr. High-resolution crystal structures of distal histidine mutants of sperm whale myoglobin. J Mol Biol 234: 140-155, 1993.

84. Reisberg PI and Olson JS. Kinetic and cooperative mechanisms of ligand binding to hemoglobin. J Biol Chem 255: 4159-4169, 1980.

85. Ringe D, Petsko GA, Kerr DE, and Ortiz de Montellano PR. Reaction of myoglobin with phenylhydrazine: a molecular doorstop. Biochemistry 23: 2-4, 1984.

86. Roughton FJW. Diffusion and chemical reaction velocity as joint factors in determining the rate of uptake of oxygen and carbon monoxide by the red blood corpuscle. Proc $R$ Soc Lond 111: 1-36, 1932.

87. Ruscio JZ, Kumar D, Shukla M, Prisant MG, Murali TM, and Onufriev AV. Atomic level computational identification of ligand migration pathways between solvent and binding site in myoglobin. Proc Natl Acad Sci U S A 105: 9204-9209, 2008.

88. Salter MD, Blouin GC, Soman J, Singleton EW, Dewilde S, Moens L, Pesce A, Nardini M, Bolognesi M, and Olson JS. Determination of ligand pathways in globins: apolar tunnels versus polar gates. J Biol Chem 287: 33163-33178, 2012.

89. Samuel PP. Expression, folding, and assembly mechanisms of monomeric myoglobins and oligomeric hemoglobins. $\mathrm{PhD}$ Dissertation in Biochemistry \& Cell Biology, Rice University, Houston, TX, 2018. https://scholarship.rice.edu/ handle/1911/105154 (accessed October 7, 2019).

90. Samuel PP, Ou WC, Phillips GN, Jr., and Olson JS. Mechanism of human apohemoglobin unfolding. Biochemistry 56: 1444-1459, 2017.

91. Samuel PP, Smith LP, Phillips GN, Jr., and Olson JS. Apoglobin stability is the major factor governing both cell-free and in vivo expression of holomyoglobin. $J$ Biol Chem 290: 23479-23495, 2015.

92. Schmidt M, Nienhaus K, Pahl R, Krasselt A, Anderson S, Parak F, Nienhaus GU, and Srajer V. Ligand migration pathway and protein dynamics in myoglobin: a timeresolved crystallographic study on L29W MbCO. Proc Natl Acad Sci U S A 102: 11704-11709, 2005.

93. Schotte F, Soman J, Olson JS, Wulff M, and Anfinrud PA. Picosecond time-resolved X-ray crystallography: probing protein function in real time. J Struct Biol 147: 235-246, 2004.

94. Scott EE and Gibson QH. Ligand migration in sperm whale myoglobin. Biochemistry 36: 11909-11917, 1997.

95. Scott EE, Gibson QH, and Olson JS. Mapping the pathways for $\mathrm{O} 2$ entry into and exit from myoglobin. $J$ Biol Chem 276: 5177-5188, 2001.

96. Scott EE, Paster EV, and Olson JS. The stabilities of mammalian apomyoglobins vary over a 600 -fold range and can be enhanced by comparative mutagenesis. J Biol Chem 275: 27129-27136, 2000.

97. Smagghe BJ, Hoy JA, Percifield R, Kundu S, Hargrove MS, Sarath G, Hilbert JL, Watts RA, Dennis ES, Peacock WJ, Dewilde S, Moens L, Blouin GC, Olson JS, and Appleby CA. Review: correlations between oxygen affinity and sequence classifications of plant hemoglobins. Biopolymers 91: 10831096, 2009. 
98. Smith LP. The effects of amino acid substitution on apomyoglobin stability, folding intermediates, and holoprotein expression. PhD Dissertation in Biochemistry \& Cell Biology, Rice University, Houston, TX, 2003. https:// scholarship.rice.edu/handle/1911/18562 (accessed October 7, 2019).

99. Smith RD, Blouin GC, Johnson KA, Phillips GN, Jr., and Olson JS. Straight-chain alkyl isocyanides open the distal histidine gate in crystal structures of myoglobin. Biochemistry 49: 4977-4986, 2010.

100. Springer BA, Sligar SG, Olson JS, and Phillips GN. Mechanisms of ligand recognition in myoglobin. Chem Rev 94: 699-714, 1994.

101. Srajer V, Ren Z, Teng TY, Schmidt M, Ursby T, Bourgeois D, Pradervand C, Schildkamp W, Wulff M, and Moffat K. Protein conformational relaxation and ligand migration in myoglobin: a nanosecond to millisecond molecular movie from time-resolved Laue X-ray diffraction. Biochemistry 40: 13802-13815, 2001.

102. St. George RC and Pauling L. The combining power of hemoglobin for alkyl isocyanides, and the nature of the hemeheme interactions in hemoglobin. Science 114: 629-634, 1951.

103. Storz J. (2018) Hemoglobin: Insights into Protein Structure, Function, and Evolution. Oxford, United Kingdom: Oxford University Press.

104. Storz JF, Runck AM, Sabatino SJ, Kelly JK, Ferrand N, Moriyama H, Weber RE, and Fago A. Evolutionary and functional insights into the mechanism underlying highaltitude adaptation of deer mouse hemoglobin. Proc Natl Acad Sci U S A 106: 14450-14455, 2009.

105. Talbot B, Brunori M, Antonini E, and Wyman J. Studies on the reaction of isocyanides with haemproteins. I. Equilibria and kinetics of the binding to the isolated chains of human haemoglobin. J Mol Biol 58: 261-276, 1971.

106. Teng TY, Srajer V, and Moffat K. Initial trajectory of carbon monoxide after photodissociation from myoglobin at cryogenic temperatures. Biochemistry 36: 12087-12100, 1997.

107. Tilton RF, Jr., Kuntz ID, Jr., and Petsko GA. Cavities in proteins: structure of a metmyoglobin-xenon complex solved to $1.9 \AA$ A. Biochemistry 23: 2849-2857, 1984.

108. Tsai AL, Berka V, Martin E, and Olson JS. A "sliding scale rule" for selectivity among $\mathrm{NO}, \mathrm{CO}$, and $\mathrm{O}(2)$ by heme protein sensors. Biochemistry 51: 172-186, 2012.

109. Tsai AL, Martin E, Berka V, and Olson JS. How do hemeprotein sensors exclude oxygen? Lessons learned from cytochrome c', nostoc puntiforme heme nitric oxide/ oxygen-binding domain, and soluble guanylyl cyclase. Antioxid Redox Signal 17: 1246-1263, 2012.

110. Vandegriff KD and Olson JS. Morphological and physiological factors affecting oxygen uptake and release by red blood cells. J Biol Chem 259: 12619-12627, 1984.

111. Vandegriff KD and Olson JS. A quantitative description in three dimensions of oxygen uptake by human red blood cells. Biophys J 45: 825-835, 1984.
112. Vandergon TL, Riggs CK, Gorr TA, Colacino JM, and Riggs AF. The mini-hemoglobins in neural and body wall tissue of the nemertean worm. Cerebratulus lacteus. $J$ Biol Chem 273: 16998-17011, 1998.

113. Varnado CL, Mollan TL, Birukou I, Smith BJ, Henderson DP, and Olson JS. Development of recombinant hemoglobinbased oxygen carriers. Antioxid Redox Signal 18: 2314-2328, 2013.

114. Walda KN, Liu XY, Sharma VS, and Magde D. Geminate recombination of diatomic ligands $\mathrm{CO}, \mathrm{O} 2$, and $\mathrm{NO}$ with myoglobin. Biochemistry 33: 2198-2209, 1994.

115. Yu TQ, Lapelosa M, Vanden-Eijnden E, and Abrams CF. Full kinetics of $\mathrm{CO}$ entry, internal diffusion, and exit in myoglobin from transition-path theory simulations. $\mathrm{J} \mathrm{Am}$ Chem Soc 137: 3041-3050, 2015.

116. Yuan Y, Tam MF, Simplaceanu V, and Ho C. New look at hemoglobin allostery. Chem Rev 115: 1702-1724, 2015.

Address correspondence to: Prof. John S. Olson

BioSciences Department Rice University

P. O. Box 1892, MS-140 6100 Main Street

Houston, TX 77005-1892

E-mail: olson@rice.edu

Date of first submission to ARS Central, September 10, 2019; date of acceptance, September 16, 2019.

$$
\begin{aligned}
& \text { Abbreviations Used } \\
\mathrm{Apo} & =\text { heme-lacking } \\
\mathrm{CerHb} & =\text { Cerebratulus lacteus } \mathrm{Hb} \\
\mathrm{CO} & =\text { carbon monoxide } \\
\mathrm{DTT} & =\text { dithiothreitol } \\
\mathrm{Hb} & =\text { hemoglobin } \\
\mathrm{HbA} & =\text { hemoglobin } \mathrm{A} \\
\mathrm{HbF} & =\text { human fetal hemoglobin } \\
\mathrm{HBOC} & =\text { hemoglobin-based oxygen carrier } \\
\text { heme } & =\text { ferroprotoporphyrin IX } \\
\text { hemin } & =\text { ferriprotoporphyrin IX } \\
\mathrm{Mb} & =\text { myoglobin } \\
\mathrm{met}- & =\text { ferric oxidation state } \\
\mathrm{NO} & =\text { nitric oxide } \\
\mathrm{NOD} & =\text { nitric oxide dioxygenation } \\
\mathrm{rHb} & =\text { recombinant hemoglobin } \\
\mathrm{rHBC} & =\text { recombinant hemoglobin-based } \\
\mathrm{S} / \mathrm{A}= & \text { oxygen carrier } \\
\mathrm{SwMb} & =\text { sperm whale Mb }
\end{aligned}
$$

